\title{
Vanishing Wealth, Vanishing Votes? Latino Homeownership and the 2016 Election in Florida
}

Jacob Rugh

Brigham Young University - Provo, jacob_rugh@byu.edu

Follow this and additional works at: https://scholarsarchive.byu.edu/facpub

Part of the Race and Ethnicity Commons

\section{Original Publication Citation}

Rugh, Jacob S. 2019. "Vanishing Wealth, Vanishing Votes? Latino Homeownership and the 2016 Election in Florida." Journal of Ethnic and Migration Studies. https://doi.org/10.1080/ 1369183X.2019.1592877

\section{BYU ScholarsArchive Citation}

Rugh, Jacob, "Vanishing Wealth, Vanishing Votes? Latino Homeownership and the 2016 Election in Florida" (2019). Faculty Publications. 3138.

https://scholarsarchive.byu.edu/facpub/3138

This Peer-Reviewed Article is brought to you for free and open access by BYU ScholarsArchive. It has been accepted for inclusion in Faculty Publications by an authorized administrator of BYU ScholarsArchive. For more information, please contact ellen_amatangelo@byu.edu. 


\title{
Vanishing wealth, vanishing votes? Latino homeownership and the 2016 election in Florida
}

\author{
Jacob S. Rugh \\ Department of Sociology, Brigham Young University, Provo, UT, USA
}

\begin{abstract}
In this article, I explore how race, class, and migration influence Latino household wealth, and uncover important implications for the close 2016 US presidential election outcome in Florida. I follow over 11,000 homeowners in the Orlando area of Orange County, Florida from 2004 to 2016. To proxy for immigrant incorporation, I leverage matched voter registration records and direct observation of borrower identification - driver's license, green card/passport, or undocumented identification. Documented immigrants appear least vulnerable to foreclosure; multivariate analyses show that Latinos with undocumented identification are most vulnerable. Foreclosure and negative equity predict decreases in voter activity among Latino Democrats and Latino Independents, respectively, but not among Latino Republicans. I confirm this pattern at the precinctlevel using data on all Orange County voters. Across Florida, county-level Latino foreclosures and lagging home prices correspond to a decline in the Democratic presidential vote from 2012 to 2016. My analysis reveals the mechanisms that erase Latino home equity and how the loss of wealth may have played a role in flipping Florida from a blue state to a red state.
\end{abstract}

\section{KEYWORDS}

Latinos; wealth; immigration; housing; voting; Florida

In the recent U.S. housing crisis, Latino household wealth plummeted by nearly twothirds, more than any other group (Maroto 2016; Taylor et al. 2011). Latino homeowners experienced foreclosure most often, especially in the rapidly-growing Sunbelt states of Arizona, Florida, and Nevada (Hall, Crowder, and Spring 2015b; Reid et al. 2017; Rugh 2015a). By 2013, 23\% of Latino homeowners lost their homes to foreclosure, compared to $19 \%$ of Blacks, $11 \%$ of Asians, and $9 \%$ of Non-Hispanic Whites (Reid et al. 2017). A constellation of factors - low initial wealth, immigration, risky loans, discriminatory practices, and crashing home prices - pushed foreclosures and negative equity to record levels, and drained the primary source of Latino household assets (Keister, Vallejo, and Smith 2015; McConnell 2008; Painter and Qian 2015; Rugh 2015a; Rugh and Massey 2010).

After an uneven recovery, median White family wealth remains 8 times that of Latino families and 10 times that of Black families (Lei et al. 2017). Compared to the deep scholarship on the Black-White wealth gap (e.g. Conley 2010; Killewald 2013; Oliver and Shapiro 
2006; Sharkey 2013), the mechanisms behind the Latino-White wealth gap seem less clear (McConnell 2008; Vallejo and Keister 2019). Home equity shapes household fortunes and the social mobility of future generations (Keister and Moller 2000). However, to what extent does the dramatic loss of wealth among Latinos reverberate beyond the walls of their homes? In this article, I explore how race, class, and migration influence foreclosures and home equity among the fast-growing and diverse Latino population of the Orlando, Florida region. I uncover mechanisms that jeopardise Latino ownership, home equity, and social mobility and argue that the loss of Latino wealth matters to broader society because it helped play a role shifting the US presidential election outcome in Florida from 2012 to 2016.

\section{Orlando, Florida study setting}

The Orlando area is an important context to study Latino housing wealth for three reasons. First, like Las Vegas and Phoenix, Orlando epitomises the housing boom and bust (Glaeser, Gyourko, and Saiz 2008). The crisis dragged on longer in Orlando than elsewhere, especially in communities of colour (Kim and Cho 2016; Raymond, Wang, and Immergluck 2016). Partly due to the diversity of the state's Latino population, the impacts in Florida differ from other regions, but remain understudied (see Cahill and Franklin 2013; Kim and Cho 2016; Strom and Reader 2013 for exceptions). Second, Orlando exemplifies the impending national demographic transformation to a more multi-ethnic and Hispanic suburban majority (Frey 2018). Third, Orlando remains at the centre of the swing region in Florida - the swing state with the most electoral votes. In 2016, Florida became a red state for the first time since 2004. The margin of victory was as narrow as in 2012 - about $1 \%$ of votes cast.

Since 2000, the Orlando metro area has become majority-minority (Frey 2018). Orlando became an emerging immigrant gateway, many from South America and South Asia (Singer 2004). The foreign born population of the Orlando metro area doubled from 2000 to 2014 (Singer 2015). The Orlando area Latino population more than doubled, from 168,000 in 2000 to over 401,000 in 2016, and the Latino population share rose from $19 \%$ to $31 \%$ (US Census Bureau 2017). Unlike the rest of the US, where nearly two in three Latinos are Mexican origin, the South American origin population is larger in Orange County. While the population of Mexican origin Latinos doubled between 2000 and 2016, the Colombian population quadrupled. Unlike South Florida, Cuban Americans comprise less than 10\% of area Latinos.

The diversity of the Latino population in Orange County is punctuated by the fact that half of Latinos are Puerto Rican (US Census Bureau 2017). ${ }^{1}$ Compared to Puerto Ricans in New York, Puerto Ricans in the Orlando region are more likely to self-identify as White, live above the poverty line, and own their own homes (Duany 2010; Duany and Rodríguez 2006; Massey and Constant 2017). However, Puerto Ricans still remain disadvantaged compared to other Latino sub-populations. The net worth of Puerto Ricans is far lower than that of Cubans and native born Mexican Americans, and roughly comparable to that of first-generation Mexican immigrants (Keister, Vallejo, and Borelli 2015). Puerto Rican exceptionalism has been attributed to their residential segregation and racial stratification that resemble the experiences of African Americans more than other Hispanics (Massey and Denton 1993). However, the recent large-scale 
migration of Puerto Ricans to the South, mainly to Florida, led to a divergence from Blacks in the housing recovery (Kuebler and Rugh 2013). Because Orlando is more integrated and features a diverse Latino co-ethnic base, home ownership may be more stable among some Latinos (Flippen 2010). Whether the axis of differentiation hinges on race, ethnicity, class, nativity, or immigrant legal status is an empirical question I seek to answer in my analysis.

The final reason Orlando is ideal is to examine potential links between housing wealth and election outcomes across Florida. This rationale is illustrated by the compelling patterns across the maps in Figure 1. Panel A depicts the standardised change in home prices since 2004 for all Florida counties with available data. Panel B depicts the percentage point change from 2012 to 2016 in the Democratic share of the two-party vote total, using the same standardised scale.

The housing market recovery across Florida counties is highly variable and corresponds closely to the geographic variation in fluctuations in election outcomes. Unlike other states, lagging home prices and prolonged foreclosure timelines meant the crisis lingered beyond 2012 in Florida. In the more urban counties of Florida's largest cities, especially in Central and South Florida, the housing market gained relative to 2004 and the Democratic vote share held steady or increased relative to 2012. In Orange County (Orlando), home prices rose $16.5 \%$ above 2004 levels, and the Democratic vote share increased by 6.4 points. In contrast, across the more sparsely populated, less diverse, exurban and rural counties in the Panhandle and in between South and Central Florida, the housing market recovery was weak to nonexistent, and the Democratic vote share plummeted. In outlying exurban Hernando County, north of Tampa and coloured in red, home prices fell $6.3 \%$ since 2004 and the Democratic vote share tumbled by 20.5 points from 2012 to 2016 . This correlation may be spurious. Even if the link is robust to rival explanations, such evidence does not explain why the crisis influences the election outcome, nor the role of Latino household wealth.
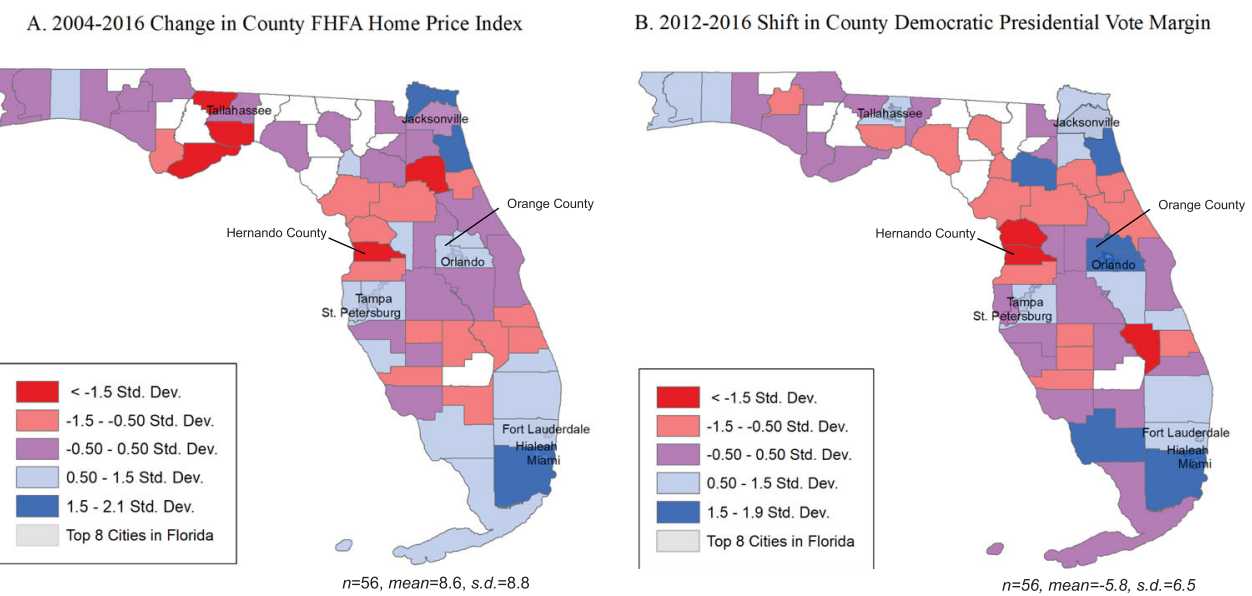

Figure 1. Change in home prices and change presidential vote by Florida County. Note: Empty counties (in white) missing home price data. Data sources: Federal home finance agency, Florida division of elections. Maps created by Author. 


\section{Contemporary Latino residential stratification and racial incorporation}

Household wealth stratifies access to home ownership, which reproduces wealth attainment and inequality. In the United States, ownership is stratified primarily by race. Black and Latino homeowners have less home equity than similarly situated White owners (Krivo and Kaufman 2004). Nationality, nativity, immigrant status, and skin tone also influence household wealth and reinforce the salience of race (Allen 2011; Emeka 2019; McConnell and Akresh 2013; Painter and Qian 2015; Salgado and Ortiz 2019; Tesfai 2017). Legal permanent residents are among the most advantaged recent immigrants in terms of home equity (McConnell and Akresh 2013). Among advantaged immigrants, disparities in income and wealth by skin tone and race still persist due colorism and racism (Goldsmith, Hamilton, and Darity 2007; Painter and Qian 2016). Discriminatory processes may racialize ostensibly nonracial social categories like immigrant legal status. The racially disparate pattern of immigrant deportation that limits Latino access to housing wealth for mixed legal status families, regardless of their individual legal status, is one example (Dreby 2015; Golash-Boza 2015; López 2015; Rugh and Hall 2016; Vallejo 2012).

What recent trends in Latino housing outcomes portend for the racial location of Latinos in future society remains contested (McConnell 2008; Tienda and Fuentes 2014). Based on intergenerational gains in home ownership, suburbanisation, and educational attainment, Latinos may trace an upward residential path toward racial incorporation into a white mainstream (Alba 2009; Myers 2007; Park and Myers 2010). Alternatively, an immigrant threat narrative may racialize Latinos, regardless of generational or legal status (Bean, Brown, and Bachmeier 2015; Chavez 2013; Massey, Durand, and Pren 2016). Ethnicity, language, external ascription, racial ideology, and homeownership may mediate racial trajectories across the life course of Latinos. These conditions dictate when and to what degree Latinos see themselves as racialized by others and how they view their own racial status (Dowling 2014; Vallejo 2012; Vargas 2015).

In sum, the racial incorporation path Latinos will follow may be upward (Alba 2009), downward (Massey 2007), blocked (Telles and Ortiz 2008), delayed (Brown 2007), segmented (Portes and Zhou 1993), or already ended at a new destination distinctive from both the historical Black and White experiences (Golash-Boza 2006; Flores-González 2017). Given the diversity of the Latino population in Florida, these trajectories may co-exist and reinforce one another.

\section{The link between foreclosures and voter outcomes}

Existing research finds moderate effects of foreclosures or negative equity and voter turnout and vote choice, depending on the context. In a national analysis, Hall, Yoder, and Karandikar $(2017,2)$ report 'precisely estimated null effects' of county-level foreclosure rates on incumbent voter shares across the 2004-2016 general elections. For individual voters in federal elections in Ohio over the same period, foreclosure at least 90 days prior to election reduces turnout by 4.6 percentage points and foreclosure within 30 days reduces turnout by 8.2 points (Hall, Yoder, and Karandikar 2017). Hall, Yoder, and Karandikar (2017) find that the effects of foreclosure in the 2016 election were 
more pronounced; nationwide, one additional foreclosure per 1,000 people reduced the county-level Democratic 2016 vote share by 0.8 to 1.8 percentage points. ${ }^{2}$

Other analyses are confined to a certain election year. In their examination of population-based credit reporting data for all California borrowers, Healy and Lenz (2017) document a strong positive effect of increased zip code mortgage delinquencies from 2006 to 2008 on the zip code Democratic (Obama) vote share in the 2008 election. Related analyses of voting patterns in California find that zip code foreclosure rates are associated with modest, yet statistically significant, decreases in voter turnout at both the neighbourhood and the individual level in the 2008 presidential election (EstradaCorrea and Johnson 2012). Likewise, among North Carolina voters in the 2010 election, McCartney (2017) uncovers a slightly stronger association between declining home prices and decreases in voter participation.

None of the existing scholarship examines estimates the interactive effects of foreclosure by race. However, mortgage distress may have indirect effects on voter participation related for residential, psychological, and economic reasons, each with a potential racially uneven impact. First, foreclosures also entail residential instability (Hall, Crowder, and Spring 2015a), which pose barriers to voter registration. Such instability may reduce the likelihood of voting because foreclosed owners are likely to be renters, who are less likely to vote than homeowners (Fischel 2001). Indeed, foreclosed homes in minority neighbourhoods in Orlando are more likely to become rental properties than foreclosed homes in White neighbourhoods (Kim and Cho 2016). The decrease in home ownership in communities of colour and shift to rental occupancy thus further compounds decreases in Democratic turnout because renters are less likely to vote - and because Black and Latino voters are more likely to be Democrats (Florida Division of Elections 2017). Moreover, homeowners who are dissatisfied are significantly more likely to be mobilised and vote compared to other homeowners and after controlling for confounders that explain differences from renter voters (Holian 2011). Thus, affluent white homeowners who be underwater on their mortgages but not still owners nonetheless may be more likely to vote.

Second, the housing crisis and ensuing recession eroded trust in institutions, including the federal government (Owens and Cook 2013; Ross and Squires 2011). Such loss of trust may also depress participation in federal elections. Because Black and Latino owners were more affected by deceptive lending practices and ensuing foreclosures, this may lower trust and reduce voter turnout. Third, foreclosures may affect participation and vote choice in federal elections because voters evaluate national economic conditions based on local factors, including foreclosure rates, even if they themselves have not experienced foreclosure (Reeves and Gimpel 2012). Reeves and Gimpel (2012) find that higher local foreclosure rates in 2008 correspond to significantly more negative assessments of the national economy on the eve of the presidential election; the effect is more pronounced among new residents and in states like Florida where foreclosure rates surged for the first time (unlike Michigan, where foreclosures rose earlier). Partisanship may bias such evaluations of local conditions. Rogers (2016) finds Tea Party movement affiliation is associated with more negative evaluations of local economic conditions, regardless of objective indicators and a host of individual and local factors. Interestingly, in their examination of election cycles over the past four decades, Healy and Malhotra (2013) find that the effects of partisan bias are more pronounced when economic performance is closer to average and 
allows for more disagreement. Accordingly, differential partisan response to foreclosure should be greater in 2016 than in 2008, when the housing market was in freefall.

Because party registration varies by race, differential partisan responses would imply differential racial responses. Crucially, Latinos exhibit greater variation in racial identification and partisan registration than Black voters. Conservative ideology is a significant predictor of White self-identification among Latinos, even controlling for skin tone and other traits (e.g. Dowling 2014; Vargas 2015). Thus, I should expect a possible partisan split in turnout patterns among Latino voters in their response to foreclosure and diminished equity, which raises two intriguing questions: First, do Latino Democrats respond more like other Latinos or more like other (Black and White) Democrats? Second, do Latino Republicans respond more like other Latinos or more like other (White) Republicans?

\section{Study design}

Figure 2 diagrams a conceptual model of my hypothesised linkages between race, homeownership, wealth, and voting outcomes. These linkages guide my three related aims. First, I seek to understand and measure the effect of wealth, income, race, ethnicity, and particularly immigrant and noncitizen status on the risk of foreclosure and homeownership exit. My second research aim is to understand the impact of lost wealth (foreclosure and home equity) on patterns of voter activity among citizen homeowners by race and party registration. The third aim is to estimate the net statistical effects of any such racial-partisan differences in foreclosures, negative equity, and voter inactivity on the shift in the Democratic vote share in the US presidential election in Orange County and across all Florida counties.

My unique panel dataset of over 9,000 homeowners from 2004 to 2016 contains a rich array of variables that facilitate my research aims (Rugh and Allen 2015; Rugh 2015b). I use linear probability models to estimate the effects of race, initial wealth, and immigrant incorporation on foreclosure and the loss of wealth, negative equity (underwater mortgage). I leverage direct observation of borrower identification - driver's license, green card/passport, or undocumented identification. Linking to voter records, I estimate the

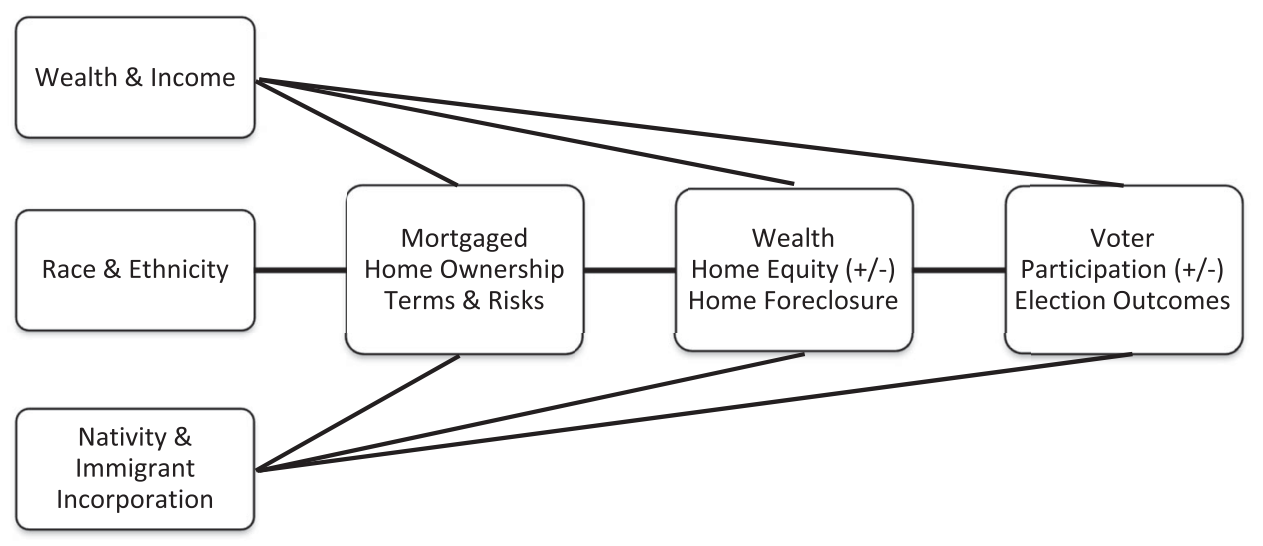

Figure 2. Conceptual model of mortgaged home ownership, wealth, and voter participation. 
interactive effects of race, party registration, foreclosure status, and negative equity on voter activity for over 5,000 matched voters. I collapse my data to the precinct-level to uncover mechanisms that document a link between housing outcomes and swings in the election results. Finally, I test the links adduced from the individual-level and precinct-level analyses at the county-level to see whether they prevail across Florida net of rival explanations.

\section{Data sources}

The primary data are 11,377 digitally scanned first lien home mortgage loans made available by the Orange County, Florida recorder, hereafter OCR. Records were collected by way of a lender-based census of all 9,792 loans originated in 2005 and 2006 by three national lenders (Rugh and Allen 2015). To sample lenders and immigrant homeowners, records based on searches for common Hispanic and Asian surnames were later added (Rugh 2015b). This supplement included 1,585 borrowers from 2004 to 2007. The OCR data feature linked loan outcomes observed through 2016: prepaid, modified, foreclosed, or completed foreclosure. ${ }^{3}$ The OCR data were merged to records of all originated mortgages in Orange County disseminated under the Home Mortgage Disclosure Act (FFIEC 2006, 2011), which resulted in 9,618 first-lien matched loans. To investigate the implications for voting, individual-level voter registration data as of December 2015 from the Orange County, Florida Supervisor of Elections (OCE) were also merged $(N=5,150){ }^{4}$

\section{Methods}

I utilise different approaches at three different levels of analysis: individual borrowers, Orange County voter precincts, and Florida counties. I examine the bivariate associations among variables of conceptual interest: race, immigration status, class, foreclosure, home equity, and voter outcomes. I explore whether any associations persist after accounting for other factors using multivariate models. Following my conceptual model, I estimate four outcomes: (1) borrower completed foreclosure, (2) voter inactive status, (3) precinct-level and (4) county-level net shift in Democratic vote share. To facilitate variable interactions and cross-model comparisons, I use ordinary least squares instead of logistic regression to estimate linear probability models for discrete outcomes (Mood 2010). ${ }^{5}$

I employ three measures to operationalise race, ethnicity, and immigrant and civic incorporation. To create a final race/ethnicity variable, I first use the OCE registered voter self-reported race (Hispanic separate race), followed by the matched HMDA race/ ethnicity (Hispanic any race), and then the US Census surname imputation variables (see the online supplement). To proxy for immigrant integration, the identification types were divided into three categories: driver's license $(N=8,414)$, foreign passport/ Legal Permanent Resident (green) card $(N=121)$, and other forms of identification $(N$ $=845$, including blank entries, $N=229$ ). The driver's license category was cross-referenced with voter registration data and re-classified as registered voters $(N=4,429,47 \%)$ and unregistered voters with driver's licenses $(N=3,985,42 \%)$.

Several different variables capture differences in income, wealth, and social class. Following Reid et al. (2017), I define a categorical variable based on the calculated ratio of borrower household income to the annual area median income (AMI) for the Orlando 
area (low/moderate, middle, upper income). To proxy for wealth, I rely on a binary variable for simultaneous second loan receipt and two additional continuous variables that capture home equity (constant $\$$ ) and the original combined loan-to-value ratio (OCLTV). ${ }^{6}$ Control variables were merged to the OCR-HMDA-OCE dataset at the zip code and block group level and are described in the online supplement.

\section{Descriptive statistics results}

Completed foreclosure is a well-defined event that erases the principal source of household wealth. As Table 1 illustrates, foreclosure was not rare in the Orlando area: nearly one in five sample borrowers who took out home loans in 2004-2007 lost their homes by 2016 . The differences in foreclosure by race and civic/immigrant integration are striking. Only $15 \%$ of White and Asian owners lost their homes, compared to $18 \%$ of Blacks and $27 \%$ of Latinos. Compared to registered voters, foreclosure rates are significantly higher among owners with driver's licenses but who are not registered to vote, regardless of race. The sample sizes for documented immigrants with valid passports and Legal Permanent Residency (hereafter LPR or green cards) are small, but foreclosure rates for Latino documented immigrants are notably lower $(20.5 \%, N=44)$. Rates are elevated for borrowers with no identification and no voter registration, and significantly higher among Latino borrowers $(35.6 \%)$ compared to registered Latino voters. This residual identification category includes both documented owners with weak civic attachment and undocumented immigrants. A small, nontrivial fraction of homeowners may be undocumented (McConnell 2015; Rugh and Allen 2015; Zayas 2015).

Table 2 reports the estimates of median home equity by race and by civic/immigrant integration status at loan origination and termination or December 2016. The median borrower had $\$ 36,978$ in home equity at origination and $-\$ 8,552$ by 2016 . Although all lost equity in the housing crash, the typical Black and Latino borrower began with a much smaller cushion and ended up much worse off. Among White, Asian, and Latino borrowers, foreign nationals with passports and documented immigrants with green cards (LPR) enjoyed the highest levels of median initial equity, consistent with McConnell and Akresh (2013). By 2016, registered voters with Driver's licenses had the highest levels of home equity, except among Black borrowers. Latinos with no documented identification stand out for their low levels of initial equity, \$11,500, and end equity, $-\$ 22,391$.

Table 1. Completed foreclosure rates by identification used to sign mortgage note, registered voter status, and race of borrower: Orange County, FL, 2004-2007 loans as of December 2016.

\begin{tabular}{lccccc}
\hline & NH White & NH Asian/Pacific Islander & NH Black & Hispanic/Latino & Total \\
\hline Driver's License, & $11.8 \%$ & $11.9 \%$ & $14.5 \%$ & $22.3 \%$ & $15.6 \%$ \\
Registered Voter & 1,861 & 421 & 691 & 1,430 & 4,403 \\
Driver's License, & $19.2 \% * * *$ & $17.2 \% *$ & $24.1 \% \%^{* * *}$ & $30.4 \% \%^{* *}$ & $23.4 \% * * *$ \\
Not Registered Voter & 1,632 & 640 & 457 & 1,475 & 4,204 \\
Green Card, Passport, & $18.2 \%$ & $12.5 \%$ & $20.0 \%$ & $20.5 \%$ & $18.5 \%$ \\
Not Registered Voter & 11 & 16 & 10 & 44 & 81 \\
Other Identification, & $16.7 \%$ & $12.9 \%$ & $13.7 \%$ & $35.6 \% * * *$ & $23.2 \% * * *$ \\
Not Registered Voter & 162 & 62 & 51 & 177 & 452 \\
Percent Foreclosed & $15.3 \%$ & $14.9 \%$ & $18.1 \%$ & $26.9 \%$ & $19.6 \%$ \\
$N$ & 3,666 & 1,139 & 1,209 & 3,126 & 9,140 \\
\hline$* * * p<.001{ }^{* *} p<.01{ }^{*} p<.05$ (two-tailed test of difference from Driver's License/Registered Voter). See paper for data \\
sources.
\end{tabular}


Table 2. Median estimated home equity $(\$)$ at origination and end of loan by identification type, registered voter status, and race of borrower: Orange County, FL, 2004-2016.

\begin{tabular}{lccrrr}
\hline & NH White & NH Asian/Pacific Islander & NH Black & Hispanic/Latino & Total \\
\hline Driver's License, & 47,500 & 48,678 & 35,625 & 35,813 & 40,500 \\
Registered Voter & $-1,556$ & 7,891 & $-13,128$ & $-11,276$ & $-6,048$ \\
Driver's License, & 35,513 & 45,000 & 26,250 & 21,420 & 31,806 \\
Not Registered Voter & $-6,381$ & 2,321 & $-18,544$ & $-18,334$ & $-11,315$ \\
Green Card, Passport, Not & 61,020 & 55,900 & 12,425 & 38,605 & 42,620 \\
Registered Voter & $-25,810$ & 206 & $-11,769$ & $-17,179$ & $-14,746$ \\
Other Identification, & 39,500 & 49,750 & 22,000 & 11,500 & 33,163 \\
Not Registered Voter & $-6,978$ & 1,609 & $-9,860$ & $-22,391$ & $-12,523$ \\
Equity at Origination & 41,250 & 46,563 & 31,958 & 29,056 & 36,978 \\
Equity at End of Loan & $-3,618$ & 4,825 & $-15,054$ & $-15,357$ & $-8,552$ \\
\hline
\end{tabular}

Note: See paper for data sources.

\section{Multivariate analysis results}

Table 3 reports the linear probability model (LPM) estimates of completed foreclosure, the first key outcome in my conceptual model (Figure 1). In the baseline specification in column (1), Latinos and Blacks are predicted to have statistically significantly higher foreclosure rates compared to Whites, 11.6 percentage points $(p<.001)$ and 2.8 points $(p$ $<.05)$ higher, respectively. After adding the immigrant integration variable and lender fixed effects to account for sample design, the Latino-White and Black-White gaps remain significant and essentially unchanged. Borrowers with driver's licenses, but not registered to vote $(7.1$ points, $p<.001)$ and undocumented identification ( 6.0 points, $p$ $<.01)$ are significantly more likely to lose their home to foreclosure than registered voters. However, documented immigrants and LPRs are no less likely to complete foreclosure.

After introducing the relevant borrower and loan controls in column (3) of Table 3 and the block group controls and zip code home price change to the full model in column (4), two key findings emerge. First, underwater borrowers are more likely to complete foreclosure $(14.5$ points, $p<.001)$, especially Black and Latino borrowers. Net of other factors, the gap in foreclosure between Latinos with negative equity and Whites with positive equity is 22.9 points $(p<.001)$; the comparable Black-White gap is 19.9 points $(p<.05)$. Second, unregistered voters with driver's licenses remain significantly more likely to complete foreclosure, and the gap between registered voters and undocumented identification borrowers is entirely driven by the interaction with Latino borrowers. In the full model, the predicted gap in foreclosure rates between Latino borrowers without formal identification or who may be undocumented and White borrowers registered to vote remains significant and substantial, at 9.1 points $(p<.05)$. Therefore, even when controlling for marital status, income, home price changes, and other factors, Latino borrowers remain most likely to complete foreclosure, partly due to low initial levels of equity (wealth) and the higher incidence of undocumented identification and possible unauthorised immigrant status. Regardless of race, however, documented immigrants were not significantly more likely to complete foreclosure.

What were the ramifications of foreclosure for the most incorporated group, registered voters? Table 4 reports estimates of voter inactive status as of December 2015, just prior to the 2016 presidential primaries and general election, the next key outcome in my conceptual model (Figure 1). The baseline specification in column (1) includes race/ethnicity, 
Table 3. LPM estimates of completed foreclosure, Orange County, FL Sample, 2004-2016.

\begin{tabular}{|c|c|c|c|c|}
\hline & (1) & $(2)$ & (3) & (4) \\
\hline \multicolumn{5}{|l|}{ Race/Ethnicity } \\
\hline NH White (ref) & - & - & - & - \\
\hline NH Asian/NHPI & $\begin{array}{c}-0.004 \\
(0.012)\end{array}$ & $\begin{array}{l}-0.014 \\
(0.014)\end{array}$ & $\begin{array}{l}0.009 \\
(0.015)\end{array}$ & $\begin{array}{l}0.003 \\
(0.016)\end{array}$ \\
\hline NH Black & $\begin{array}{c}0.028^{*} \\
(0.013)\end{array}$ & $\begin{array}{l}0.027^{*} \\
(0.012)\end{array}$ & $\begin{array}{r}-0.022^{*} \\
(0.011)\end{array}$ & $\begin{array}{r}-0.031^{* *} \\
(0.011)\end{array}$ \\
\hline Hispanic/Latino & $\begin{array}{c}0.116^{* * *} \\
(0.010)\end{array}$ & $\begin{array}{c}0.106^{* * *} \\
(0.010)\end{array}$ & $\begin{array}{l}0.002 \\
(0.018)\end{array}$ & $\begin{array}{c}-0.001 \\
(0.018)\end{array}$ \\
\hline Underwater (Negative Equity) & & & $\begin{array}{c}0.130^{* * *} \\
(0.018)\end{array}$ & $\begin{array}{c}0.145^{* * *} \\
(0.013)\end{array}$ \\
\hline NH Asian/NHPI * Underwater & & & $\begin{array}{c}-0.001 \\
(0.024)\end{array}$ & $\begin{array}{l}0.004 \\
(0.024)\end{array}$ \\
\hline NH Black * Underwater & & & $\begin{array}{c}0.045^{*} \\
(0.020)\end{array}$ & $\begin{array}{r}0.054^{* *} \\
(0.021)\end{array}$ \\
\hline Hispanic/Latino * Underwater & & & $\begin{array}{c}0.078^{* * *} \\
(0.017)\end{array}$ & $\begin{array}{c}0.084^{* * *} \\
(0.018)\end{array}$ \\
\hline \multicolumn{5}{|l|}{ Immigrant Incorporation } \\
\hline Driver's License, Registered Voter (ref) & - & - & - & - \\
\hline Driver's License, Not Registered Voter & & $\begin{array}{c}0.071^{* * *} \\
(0.022)\end{array}$ & $\begin{array}{r}0.044^{* * *} \\
(0.008)\end{array}$ & $\begin{array}{c}0.043^{* * * *} \\
(0.008)\end{array}$ \\
\hline Green Card/Foreign Passport & & $\begin{array}{l}0.022 \\
(0.045)\end{array}$ & $\begin{array}{c}-0.015 \\
(0.043)\end{array}$ & $\begin{array}{c}-0.016 \\
(0.043)\end{array}$ \\
\hline Other Identification & & $\begin{array}{r}0.060^{* *} \\
(0.020)\end{array}$ & $\begin{array}{c}-0.001 \\
(0.020)\end{array}$ & $\begin{array}{l}0.001 \\
(0.020)\end{array}$ \\
\hline Other ID * Hispanic Surname Borrower & & & $\begin{array}{c}0.082^{*} \\
(0.041)\end{array}$ & $\begin{array}{c}0.091^{*} \\
(0.042)\end{array}$ \\
\hline Lender Fixed Effects & No & Yes & Yes & Yes \\
\hline Borrower \& Loan Controls & No & No & Yes & Yes \\
\hline Year of Origination Fixed Effects & No & No & Yes & Yes \\
\hline Census Block Group Controls & No & No & No & Yes \\
\hline Zip Code Change in Home Values & No & No & No & Yes \\
\hline$R^{2}$ & 0.02 & 0.03 & 0.11 & 0.11 \\
\hline$N$ & 9,397 & 9,397 & 9,115 & 9,003 \\
\hline Mean VIF & 1.08 & 1.21 & 2.50 & 2.47 \\
\hline
\end{tabular}

OLS linear probability model coefficients (robust standard errors) ${ }^{* *} p<.001{ }^{* *} p<.01{ }^{*} p<.05$ (two-tailed tests) Borrower \& loan controls: Ratio of income to area median income (AMI) category, original combined Loan-to-Value ratio (OCLTV), high cost subprime loan, loan purpose, occupancy, condominium property, amount of loan, Government-sponsored Enterprise (GSE) purchased loan, loan type, adjustable rate (ARM), and prepayment penalty indicator. Census block group controls: Percent Hispanic, percent foreign born, percent owner-occupied homes, percent of adults with a college degree, and median year housing structure built. Lender fixed effects account for different primary sample lenders and a category for the surname sample supplement across all lenders. See paper text for data sources.

party registration, and foreclosure status. A racial gap in voter inactivity is significant only between Latinos and Whites, but is quite modest, at just 2.0 points $(p<.05)$. There are no differences by party. However, those in foreclosure are 4.6 points $(p<.001)$ more likely to become inactive voters than those who never enter foreclosure, regardless of race or party.

In column (2) of Table 4, an interaction of party registration with race is added to the model of voter inactive status. Compared to White Republicans, Latino Democrats are the only cross-classified group predicted to be inactive voters at a higher rate (5.6 points, $p$ $<.01)$. The coefficient on ever in foreclosure remains unchanged, implying a 4.6-point gap $(p<.001)$. In column (3), a three-way interaction of race, party, and ever in foreclosure is introduced to the model along with controls for voter decade of birth and sex. The effect of the two-way interaction with Latino and Democratic voter status becomes insignificant and the one-way effect of foreclosure remains consistent at 4.6 points $(p<.001)$. The only three-way interaction that emerges as statistically significant is the coefficient associated 
Table 4. LPM Estimates of inactive voter status, matched sample in Orange County, 2015.

\begin{tabular}{|c|c|c|c|c|}
\hline & (1) & (2) & (3) & (4) \\
\hline \multicolumn{5}{|l|}{ Race/Ethnicity } \\
\hline NH White (ref) & - & - & - & - \\
\hline NH Asian/NHPI & $\begin{array}{c}-0.001 \\
(0.011)\end{array}$ & $\begin{array}{l}0.001 \\
(0.018)\end{array}$ & $\begin{array}{c}-0.001 \\
(0.019)\end{array}$ & $\begin{array}{r}-0.007 \\
(0.019)\end{array}$ \\
\hline NH Black & $\begin{array}{c}-0.005 \\
(0.616)\end{array}$ & $\begin{array}{l}0.012 \\
(0.041)\end{array}$ & $\begin{array}{c}0.049 \\
(0.060)\end{array}$ & $\begin{array}{c}0.047 \\
(0.061)\end{array}$ \\
\hline Hispanic/Latino & $\begin{array}{l}0.020^{*} \\
(0.008)\end{array}$ & $\begin{array}{c}-0.009 \\
(0.014)\end{array}$ & $\begin{array}{r}0.008 \\
(0.017)\end{array}$ & $\begin{array}{r}0.004 \\
(0.018)\end{array}$ \\
\hline \multicolumn{5}{|l|}{ Party Registration } \\
\hline \multirow{2}{*}{$\begin{array}{l}\text { Republican Party (REP) } \\
\text { Other Party (OTH) }\end{array}$} & - & - & - & - \\
\hline & $\begin{array}{l}0.018 \\
(0.009)\end{array}$ & $\begin{array}{l}0.020 \\
(0.013)\end{array}$ & $\begin{array}{r}0.006 \\
(0.013)\end{array}$ & $\begin{array}{r}0.005 \\
(0.014)\end{array}$ \\
\hline Democratic Party (DEM) & $\begin{array}{l}0.006 \\
(0.008)\end{array}$ & $\begin{array}{c}-0.012 \\
(0.010)\end{array}$ & $\begin{array}{r}-0.006 \\
(0.011)\end{array}$ & $\begin{array}{r}-0.006 \\
(0.011)\end{array}$ \\
\hline $\mathrm{NH}$ Asian/NHPI * OTH & & $\begin{array}{c}-0.018 \\
(0.027)\end{array}$ & $\begin{array}{c}-0.013 \\
(0.027)\end{array}$ & $\begin{array}{r}-0.004 \\
(0.027)\end{array}$ \\
\hline $\mathrm{NH}$ Asian/NHPI * DEM & & $\begin{array}{l}0.013 \\
(0.027)\end{array}$ & $\begin{array}{r}-0.013 \\
(0.025)\end{array}$ & $\begin{array}{r}-0.006 \\
(0.025)\end{array}$ \\
\hline NH Black * OTH & & $\begin{array}{l}0.001 \\
(0.050)\end{array}$ & $\begin{array}{c}0.007 \\
(0.072)\end{array}$ & $\begin{array}{r}0.008 \\
(0.073)\end{array}$ \\
\hline $\mathrm{NH}$ Black * DEM & & $\begin{array}{c}-0.010 \\
(0.042)\end{array}$ & $\begin{array}{c}-0.054 \\
(0.061)\end{array}$ & $\begin{array}{r}-0.058 \\
(0.062)\end{array}$ \\
\hline Hispanic/Latino * OTH & & $\begin{array}{c}-0.010 \\
(0.022)\end{array}$ & $\begin{array}{c}0.014 \\
(0.026)\end{array}$ & $\begin{array}{c}0.014 \\
(0.026)\end{array}$ \\
\hline Hispanic/Latino * DEM & & $\begin{array}{l}0.056^{* *} \\
(0.019)\end{array}$ & $\begin{array}{r}0.023 \\
(0.022)\end{array}$ & $\begin{array}{r}0.019 \\
(0.023)\end{array}$ \\
\hline \multicolumn{5}{|l|}{ Ever in Foreclosure } \\
\hline Foreclosure & $\begin{array}{l}0.046^{* * *} \\
(0.008)\end{array}$ & $\begin{array}{l}0.046^{* * *} \\
(0.008)\end{array}$ & $\begin{array}{c}0.046^{*} \\
(0.019)\end{array}$ & $\begin{array}{r}0.043^{3} \\
(0.020)\end{array}$ \\
\hline Foreclosure * NH Asian/NHPI * OTH & & & $\begin{array}{c}-0.009 \\
(0.074)\end{array}$ & $\begin{array}{r}0.006 \\
(0.075)\end{array}$ \\
\hline Foreclosure * NH Asian/NHPI * DEM & & & $\begin{array}{c}0.074 \\
(0.070)\end{array}$ & $\begin{array}{r}0.088 \\
(0.070)\end{array}$ \\
\hline Foreclosure * NH Black * OTH & & & $\begin{array}{c}-0.038 \\
(0.102)\end{array}$ & $\begin{array}{c}-0.037 \\
(0.103)\end{array}$ \\
\hline Foreclosure * NH Black * DEM & & & $\begin{array}{r}0.106 \\
(0.087)\end{array}$ & $\begin{array}{r}0.108 \\
(0.087)\end{array}$ \\
\hline Foreclosure * Hispanic/Latino * OTH & & & $\begin{array}{c}-0.002 \\
(0.050)\end{array}$ & $\begin{array}{r}-0.002 \\
(0.051)\end{array}$ \\
\hline Foreclosure * Hispanic/Latino * DEM & & & $\begin{array}{c}0.092^{*} \\
(0.042)\end{array}$ & $\begin{array}{r}0.099^{*} \\
(0.043)\end{array}$ \\
\hline Voter Decade of Birth \& Sex & No & No & Yes & Yes \\
\hline Borrower Income \& Loan Controls & No & No & No & Yes \\
\hline$R^{2}$ & .01 & .01 & .02 & .03 \\
\hline$N$ & 5,083 & 5,083 & 5,083 & 5,083 \\
\hline
\end{tabular}

with Latino Democrats ever in foreclosure. The point estimate implies a 9.2 percentage point gap $(p<.05)$ in inactive voter status compared to White Republicans ever in foreclosure and a 13.8 point gap versus White Republicans never in foreclosure. These gaps estimated for Latino Democrats ever in foreclosure remain essentially the same, at 9.9 and 14.2 points, respectively, even after controlling for borrower income, marital status, and other significant factors in column (4).

Figure 3 depicts the predicted estimates of the inactive voter share for Whites and Latinos by party and foreclosure status based on the final estimates in Table 3. Net of other factors, White Democrats and Latino Republicans are least likely to be inactive, only about $5 \%$, regardless of foreclosure status. Likewise, similar shares of White Republicans are estimated to be inactive voters; the share for White Republicans in foreclosure is 


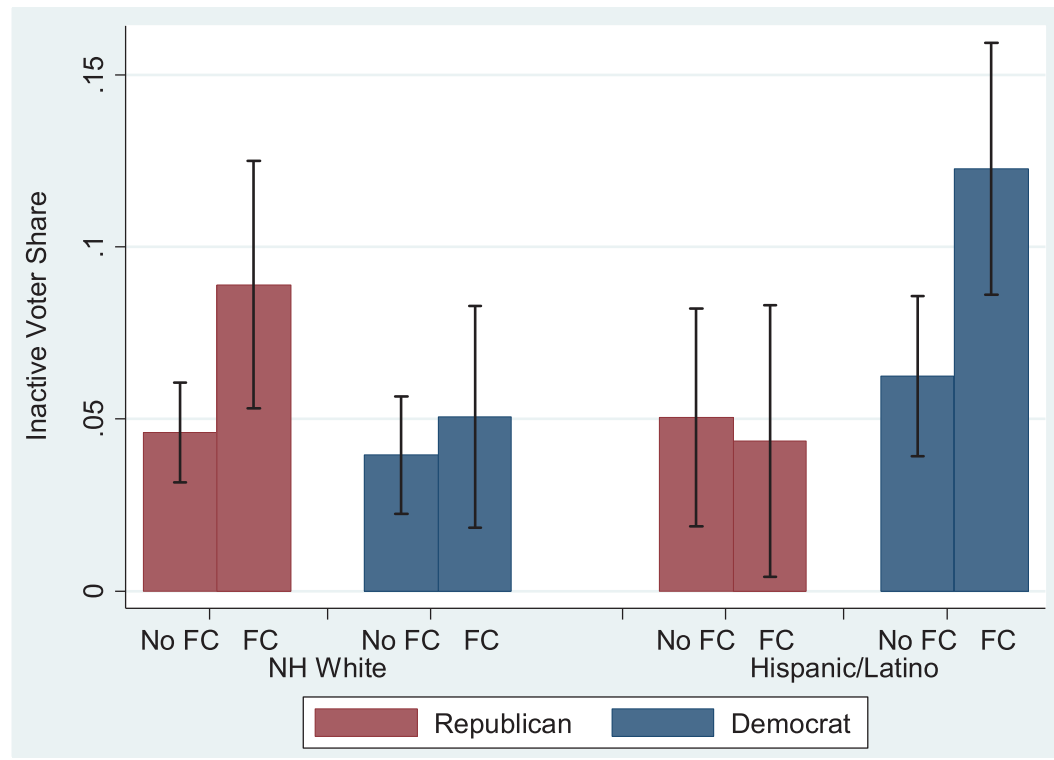

Figure 3. Regression-adjusted inactive voter share by party and ever in foreclosure (FC), matched sample of non-Hispanic white and Hispanic/Latino registered voters, Orange County, FL, 2015 (See Table 3 for full results).

higher, but the confidence intervals overlap, and are not significantly different given the sample size. The only contrast that is statistically significant is among Latino Democrats by foreclosure status. This predicted effect has potential for greater impact because more Latinos are registered Democrats who have also entered foreclosure: $21 \%$ of sample Latino homeowner voters are Democrats ever in foreclosure, versus only $9 \%$ of White voters.

Being underwater or having negative equity is more common than foreclosure. While $33 \%$ of White borrowers entered foreclosure, $55 \%$ ended their loans in negative equity by 2016. Similarly, $50 \%$ of Latino borrowers entered foreclosure, and an astounding $68 \%$ ended with negative equity. Figure 4 depicts estimates of voter inactivity from Table 4 after replacing the foreclosure variable as an indicator for lost wealth with a variable for underwater or negative equity status (see online supplement). The effect of underwater status among Latinos not affiliated with the two major parties is significant. The estimates suggest that these unaffiliated Latino voters are over three times as likely to be inactive if they end up with negative equity $(10.6 \%$ versus $3.3 \%, p<.03)$. About $21 \%$ of Latino voters were other/no party voters were underwater, compared to only $12 \%$ of White voters. The estimates for Latino Democrats are marginally significant $(p<.13)$. Strikingly, Figure 4 shows there is no distinguishable difference in voter inactivity rates between White Republicans and Latino Republicans, across race or underwater status.

I now examine the last link in my conceptual chain: the effects of lost household wealth on election outcomes. Specifically, is diminished wealth related to the decrease in the Democratic US presidential two-party vote share in Florida from 2012 to 2016? I examine whether foreclosures and lost wealth affect the net shift in Democratic vote shares at two levels, first, the Orange County, Florida precinct-level and, second, at the Florida county-level. I collapse my unique panel dataset to the precinct level and estimate 


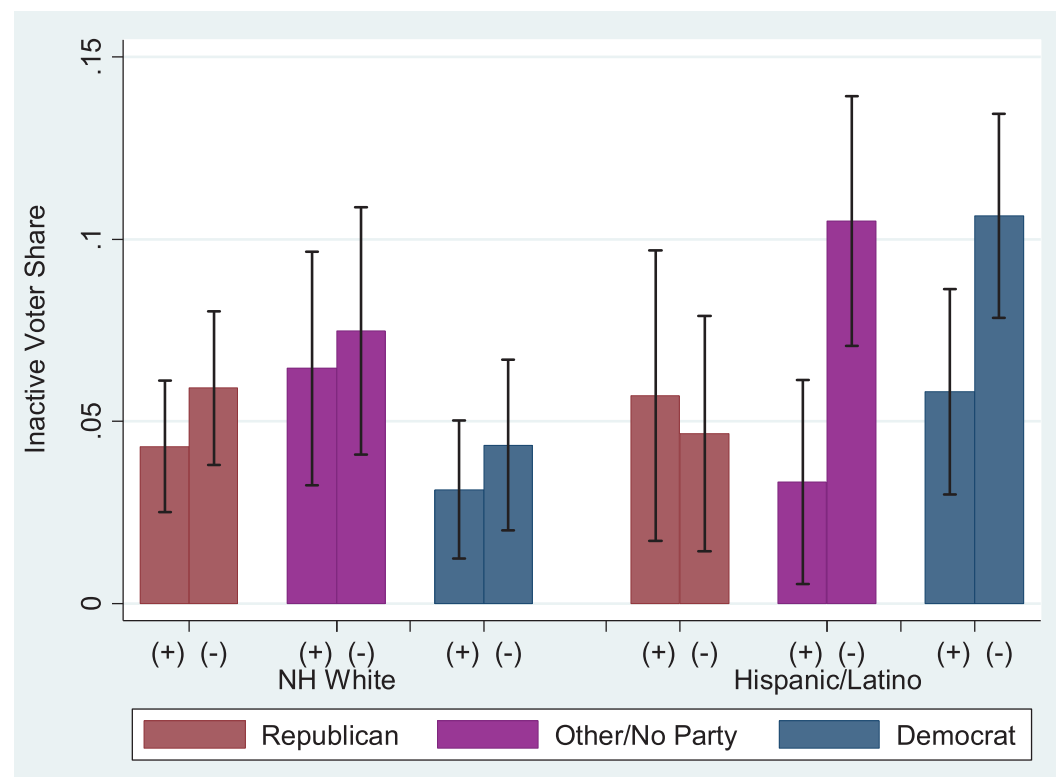

Figure 4. Regression-adjusted inactive voter share by party and positive (+) or negative (-) equity mortgage loan status, matched sample of non-Hispanic white and Hispanic/Latino registered voters, Orange County, FL, 2015 (See Table 3 for full results).

the shift in Democratic vote shares (net of the +3.4 -point shift countywide) as a function of race-specific aggregate percentages of ending in foreclosure, underwater, and overall inactive voter status. For inactive status, I collapse the records for all 782,299 Orange County voters by race registered in December 2015, not just the matched sample.

Table 5 reports the OLS estimates of precinct-level net shifts in the Democratic vote share. Other mechanisms might of course also lead to lower Democratic vote shares. Models control for the share of adults in the precinct with a college degree, among other factors (see Table 5). The results in column (1) suggest that the share of Black and Latino borrowers that ended up in foreclosure or completed foreclosure by 2016 were each significantly correlated with a negative shift, or a higher Republican vote share. Widespread foreclosures may have depressed turnout among Black voters generally. Any effect would necessarily also entail a partisan shift because $96 \%$ of Black homeowner voters in the sample are not registered as Republicans. Finally, the marginally significant $(p<.06)$ coefficient on the Latino foreclosure share is consistent with a disproportionate increase in non-Republican Latino voter inactivity prior to the election as documented in Figures 3 and 4.

Column (2) of Table 5 reports the controlled estimates of race-specific underwater statis on the net shift in the Democratic vote share. The share of White borrowers underwater is the only statistically significant determinant. A one-standard deviation (26.9 percentage points) increase in underwater White borrowers is associated with a 0.83 point net decrease in the Democratic vote share from 2012 to 2016. In contrast to the pattern among Latinos (Figure 4), a lagging housing recovery may have potentially led more White voters to vote or switch their vote to the Republican candidate (see discussion section). Column (3) reports estimates of the possible indirect effect of aggregate inactive 
Table 5. OLS estimates of precinct-level net shift in democratic presidential election vote share in Orange County, FL, 2012 to 2016.

\begin{tabular}{|c|c|c|c|c|}
\hline & (1) & $(2)$ & (3) & (4) \\
\hline \multicolumn{5}{|l|}{ Loan Delinquent/REO Repossession } \\
\hline Percent of White Borrowers Deliq/REO & $\begin{array}{c}-0.009 \\
(0.042)\end{array}$ & & & $\begin{array}{l}0.002 \\
(0.044)\end{array}$ \\
\hline Percent of API Borrowers Deliq/REO & $\begin{array}{l}0.026 \\
(0.077)\end{array}$ & & & $\begin{array}{l}0.039 \\
(0.083)\end{array}$ \\
\hline Percent of Black Borrowers Deliq/REO & $\begin{array}{r}-0.160^{*} \\
(0.056)\end{array}$ & & & $\begin{array}{r}-0.118^{*} \\
(0.057)\end{array}$ \\
\hline Percent of Latino Borrowers Deliq/REO & $\begin{array}{r}-0.049^{+} \\
(0.027)\end{array}$ & & & $\begin{array}{c}-0.036 \\
(0.029)\end{array}$ \\
\hline \multicolumn{5}{|l|}{ Home Underwater (Negative Equity) } \\
\hline Percent of White Borrowers Underwater & & $\begin{array}{c}-0.031^{* *} \\
(0.012)\end{array}$ & & $\begin{array}{r}-0.027^{*} \\
(0.012)\end{array}$ \\
\hline Percent of API Borrowers Underwater & & $\begin{array}{l}0.009 \\
(0.008)\end{array}$ & & $\begin{array}{l}0.002 \\
(0.009)\end{array}$ \\
\hline Percent of Black Borrowers Underwater & & $\begin{array}{c}-0.009 \\
(0.008)\end{array}$ & & $\begin{array}{c}-0.004 \\
(0.008)\end{array}$ \\
\hline Percent of Latino Borrowers Underwater & & $\begin{array}{c}-0.008 \\
(0.010)\end{array}$ & & $\begin{array}{c}-0.001 \\
(0.010)\end{array}$ \\
\hline \multicolumn{5}{|l|}{ Inactive Voters in 2015} \\
\hline Percent of API Voters Inactive & & & $\begin{array}{l}0.150^{* *} \\
(0.049)\end{array}$ & $\begin{array}{l}0.131^{* *} \\
(0.050)\end{array}$ \\
\hline Percent of Black Voters Inactive & & & $\begin{array}{l}0.084 \\
(0.051)\end{array}$ & $\begin{array}{l}0.075 \\
(0.052)\end{array}$ \\
\hline Percent of Latino Voters Inactive & & & $\begin{array}{c}-0.182^{* *} \\
(0.070)\end{array}$ & $\begin{array}{r}-0.150^{*} \\
(0.071)\end{array}$ \\
\hline \multicolumn{5}{|l|}{ Precinct Control Variables } \\
\hline Percent of Voters Age 65 or Older & $\begin{array}{l}0.002 \\
(0.001)\end{array}$ & $\begin{array}{l}0.002 \\
(0.001)\end{array}$ & $\begin{array}{l}0.002 \\
(0.001)\end{array}$ & $\begin{array}{l}0.003^{*} \\
(0.001)\end{array}$ \\
\hline Percent of Voters Registered Democrats & $\begin{array}{l}0.048 \\
(0.039)\end{array}$ & $\begin{array}{c}-0.018 \\
(0.033)\end{array}$ & $\begin{array}{l}0.017 \\
(0.032)\end{array}$ & $\begin{array}{l}0.035 \\
(0.040)\end{array}$ \\
\hline Percent of Adults with College Degree & $\begin{array}{l}0.196^{* * *} \\
(0.026)\end{array}$ & $\begin{array}{l}0.185^{* * * *} \\
(0.026)\end{array}$ & $\begin{array}{l}0.192^{* * *} \\
(0.024)\end{array}$ & $\begin{array}{l}0.175^{* * *} \\
(0.026)\end{array}$ \\
\hline Percent Owner-occupied Homes & $\begin{array}{c}-0.022 \\
(0.015)\end{array}$ & $\begin{array}{r}-0.030^{*} \\
(0.014)\end{array}$ & $\begin{array}{c}-0.015 \\
(0.019)\end{array}$ & $\begin{array}{c}-0.014 \\
(0.019)\end{array}$ \\
\hline Percent Change in Home Equity & $\begin{array}{l}0.013^{* *} \\
(0.005)\end{array}$ & $\begin{array}{l}0.017^{* * *} \\
(0.005)\end{array}$ & $\begin{array}{l}0.007 \\
(0.005)\end{array}$ & $\begin{array}{l}0.013^{* * *} \\
(0.005)\end{array}$ \\
\hline Adjusted $R^{2}$ & 0.37 & 0.37 & 0.38 & 0.40 \\
\hline$N$ & 208 & 208 & 208 & 208 \\
\hline
\end{tabular}

voter shares by race. ${ }^{7}$ One unexpected result is the sign on the coefficient associated with the share of Asian/NHPI voters who are inactive, which warrants further review, but is beyond the scope of my analysis. As anticipated, a large $(-0.182)$ and statistically significant $(p<.01)$ coefficient is associated with the percent of registered Latino voters that are inactive.

Column (4) of Table 5 combines the race-specific interactions of foreclosure, negative equity, and voter inactivity into a final model. The share of Black borrowers ending in foreclosure, White borrowers underwater, and inactive Latino registered voters all remain statistically significant and in the anticipated direction. Across models in Table 5, the percent of adults with a college degree is a significant, leading predictor of the net shift in the Democratic vote share, lending the models face validity and contributing to the $R^{2}$ value of 0.40 . The overall change in home equity for all borrowers, a product of initial wealth and home price recovery, remains modestly $(0.013)$, but significantly associated 
$(p<.01)$ with the net shift in precinct Democratic vote shares. The results suggest that the housing market recovery influences the net swing in the Democratic voter share from 2012 to 2016, even after controlling for well-established explanatory variables like educational attainment.

I have documented three pathways whereby the changes in housing wealth influence voter activity and outcomes in Orange County: foreclosure, negative equity, and voter inactivity. I now investigate to what extent trends across all Florida counties are consistent with precinct- and individual-level evidence presented thus far. Figure 5 plots the shift in Democratic two-party vote shares from 2012 to 2016 against the change in home values since the peak of the housing boom in June 2004 to June 2016 for Florida counties. The correlation is highly significant $(t=9.35)$. Though modest $(0.20)$, the slope is steep enough to be a contributing cause in a close election. Home prices in the more populous have recovered more than in the less populous counties, confirming the pattern in Figure 1. This correlation does not account for factors that may drive both trends, such as education and racial composition, and is still potentially spurious.

Table 6 reports the county-level estimates of the shift in the Democratic vote share as a function of the overall home price recovery and White- and Latino-specific county foreclosure rates from Rugh and Hall (2016). In the baseline model in column (1), the three housing-related measures are all significant and substantial, explaining close to half the variance. The sign on the White foreclosure coefficient is unexpected, implying more foreclosures lead to a higher Democratic vote share. However, White foreclosure rates peaked later in the crisis and corresponded to later recovery in many areas. It also remains to be

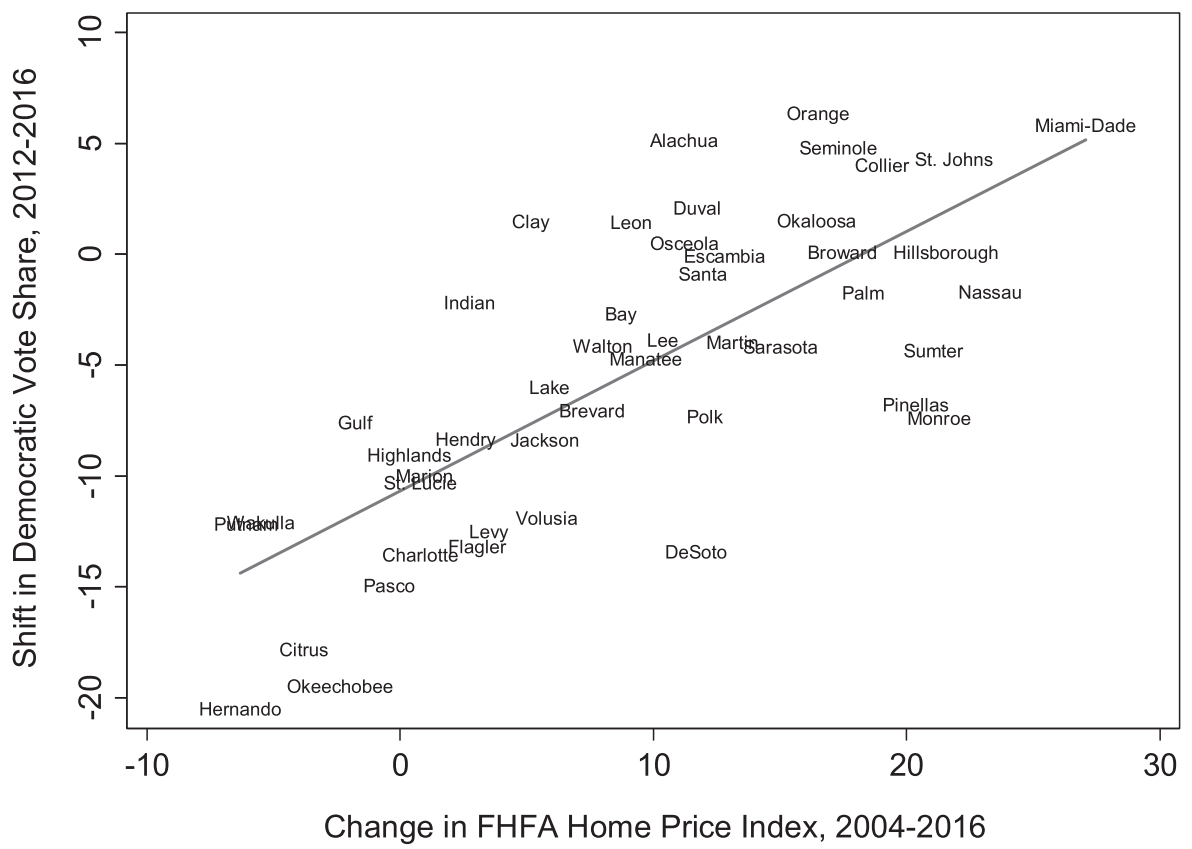

Figure 5. Florida county-level change in home values since 2004 and shift in democratic presidential vote share, 2012-2016. Data sources: Florida Division of Elections, Federal Home Finance Agency (FHFA), Author calculations. 
seen if this effect persists net of controls. As anticipated, rising home prices correspond to more Democratic votes while higher Latino foreclosure rates imply fewer Democratic votes.

The model in column (2) of Table 6 adds two leading rival explanations: the share of White adults with a college degree and percent of the population that is Latter-day Saint (LDS or Mormon); each predict significant positive shifts in the Democratic vote share relative to 2012 (Silver 2016, 2017). After adding these controls, the fraction of variance explained rises from 0.49 to 0.72 . Home prices remain significant, yet the magnitude is reduced by about two-thirds, to 0.162 . However, the magnitude of Hispanic foreclosure rates point estimate only declines slightly, from -0.449 to -0.386 . The model results in column (3) repeat the analysis in column (2), except that the FHFA home price index is replaced by the Zillow.com price index, a more volatile index arguably more reflective of the dramatic housing boom and bust in Florida. The broad pattern of results is robust to this alternative measure and the precision is increased. Given the unavailability of Zillow.com data for 14 less populous counties, column (5) presents a final model specification using the FHFA index and the share of the overall population that is White. The coefficients on FHFA home price index and Latino foreclosure rates remain significant $(p$ $<.05$ ) and little changed in magnitude, at 0.226 and -0.313 , respectively. The effect of White foreclosure rates becomes insignificant and the White percent college-educated variable remains the leading predictors of increased Democratic vote shares. The final model introduces the share of the population that is White, and the share of Hispanics that are Cuban origin. Each of these vital control variables predicts significantly lower Democratic voter shares, per expectations.

Table 6. Florida county-level OLS estimates of shift in democratic presidential election two-party vote share, 2012 to 2016.

\begin{tabular}{|c|c|c|c|c|}
\hline & (1) & $(2)$ & (3) & (4) \\
\hline \multicolumn{5}{|l|}{ Housing Crisis } \\
\hline Change in FHFA Home Price Index, 2004-2016 & $\begin{array}{l}0.472^{* * *} \\
(0.076)\end{array}$ & $\begin{array}{l}0.162^{*} \\
(0.077)\end{array}$ & & $\begin{array}{l}0.226^{* *} \\
(0.067)\end{array}$ \\
\hline Change in Zillow Home Value Index, 2004-2016 & & & $\begin{array}{l}0.199 * * \\
(0.059)\end{array}$ & \\
\hline Non-Hispanic White Foreclosure Rate, 2011 & $\begin{array}{l}2.662^{* * *} \\
(0.803)\end{array}$ & $\begin{array}{l}1.275^{*} \\
(0.634)\end{array}$ & $\begin{array}{l}1.775^{* *} \\
(0.636)\end{array}$ & $\begin{array}{l}1.068 \\
(0.554)\end{array}$ \\
\hline Hispanic/Latino Foreclosure Rate, 2011 & $\begin{array}{r}-0.449^{*} \\
(0.175)\end{array}$ & $\begin{array}{c}-0.386^{* *} \\
(0.134)\end{array}$ & $\begin{array}{r}-0.296^{*} \\
(0.132)\end{array}$ & $\begin{array}{r}-0.313^{*} \\
(0.119)\end{array}$ \\
\hline \multicolumn{5}{|l|}{ Rival Explanations } \\
\hline Percent of White Adults w/College Degree, 2010 & & $\begin{array}{l}0.424^{* * *} \\
(0.074)\end{array}$ & $\begin{array}{l}0.518^{* * *} \\
(0.056)\end{array}$ & $\begin{array}{l}0.401^{* * * *} \\
(0.057)\end{array}$ \\
\hline Percent Latter-day Saint (LDS), 2010 & & $\begin{array}{l}2.182^{*} \\
(0.944)\end{array}$ & $\begin{array}{l}3.398^{* *} \\
(1.208)\end{array}$ & $\begin{array}{l}2.435^{* *} \\
(0.802)\end{array}$ \\
\hline Percent Democratic Vote Share, 2012 & & $\begin{array}{c}-2.034 \\
(5.121)\end{array}$ & $\begin{array}{c}-5.196 \\
(5.337)\end{array}$ & \\
\hline Percent White, 2010 & & & & $\begin{array}{c}-0.085^{* *} \\
(0.032)\end{array}$ \\
\hline Percent Cuban Origin, Hispanics, 2010 & & & & $\begin{array}{c}-0.152^{* *} \\
(0.048)\end{array}$ \\
\hline Adjusted $R^{2}$ & 0.49 & 0.72 & 0.79 & 0.79 \\
\hline$N$ & 54 & 54 & 45 & 54 \\
\hline
\end{tabular}

Ordinary least squares coefficients (standard errors) ${ }^{* *} p<.001{ }^{* *} p<.01{ }^{*} p<.05$ (two-tailed tests). Data sources: Florida Division of Elections, Federal Housing Finance Administration, Zillow.com, 2010 U.S. Census, Association of Religion Data Archives Religious Congregations \& Membership Study, and Rugh and Hall (2016). 
In summary, the combined effects of the already established class, religious, racial, and ethnic origin rival explanation variables in Table 6 reduce - but do not erase - the substantial effects of house prices and Latino foreclosures on the Democratic vote shift in Florida. If the county home price index were increased by one standard deviation and Latino foreclosure rates were decreased by one standard deviation, the size of the shift in the partisan vote share from 2012 to 2016 would decrease by $49 \%$, or almost half. By comparison, for a one standard deviation decline in the White education variable, it would decline by $64 \%$.

\section{Discussion}

In this article, I have endeavoured to uncover the mechanisms that erase Latino home equity and jeopardise the social mobility of the nation's largest minority group. I find that low initial levels of home equity and higher levels of undocumented identification (including undocumented status) are two principal pathways whereby Latinos experienced the largest declines in household wealth in the Orlando region. My analysis confirms the well-known mechanism of equity risk, while my unique data on undocumented identification and foreclosure represent an original contribution to the literature on Latino residential stratification.

The causes and consequences of lost Latino home equity also matter are not confined to Latino households. This research documents the direct and indirect links between vanishing Latino wealth and vanishing Democratic votes that played a contributing role in flipping Florida from a blue state to a red state in the recent 2016 US presidential election. The final mechanism I uncover is a differential effect of lost equity and foreclosure on Latino voters by partisan registration: Home foreclosure and negative equity predict decreases in voter activity among Latino Democrats and Latino Independents, respectively, but not among Latino Republicans. Therefore, lost wealth shifted the relative composition of Latino voters such that the Latino Republican share increased, which translates into a higher-than-expected Republican vote share, which is exactly what happened in the 2016 presidential election.

Overall, three important findings emerge from my analysis.

First, I find that the disadvantaged wealth and immigrant profile of Latinos help explain why $27 \%$ lost their homes to foreclosure in the Orlando, Florida area, versus $18 \%$ of Blacks, and $15 \%$ of Whites and Asian/Pacific Islanders. Latinos had the least initial home equity and over two-thirds of Latino owners ended up with negative equity by 2016, a higher fraction than any other group. Multivariate analysis confirmed that negative equity was associated with a much significantly higher risk of foreclosure for Latinos, even compared to Whites. Income does not account for these disparities, but immigrant status appears to play a key role. Across groups, documented immigrants with passports and legal permanent residency are least vulnerable to foreclosure. Analyses confirm that Latinos with undocumented identification are by far the most vulnerable, followed by Latinos with driver's licenses, but who are not registered to vote. These findings contribute to the existing literature by documenting direct evidence that Latino immigrant and civic incorporation raise the risk of foreclosure and forgone household wealth accumulation.

Second, home foreclosure and negative equity predict significant decreases in voter activity among Latino Democrats and Latino Independents, respectively, but not among 
Latino Republicans. I find no other additional significant interactions by race, party, and foreclosure or negative equity status in my multivariate analysis of the matched homeowner-voter individual-level data. At the Orange County (Orlando) precinct-level, I combine aggregate data on over 780,000 voters and find that the proportion inactive of all Latino voters is a strong and significant determinant of a reduction, relative to 2012, in the Democratic two-party vote share in the 2016 US presidential election. A one-standard deviation change ( 7.9 percentage points) in the share of inactive Latino voters leads to a decrease in the net Democratic vote share by 1.43 points, about $42 \%$ the size of the mean precinct-level swing, 3.4 points. I also find that decreases in precinct-level home equity, increases in White owners underwater, and increases in Black foreclosures predict a negative shift or reduction in the Democratic vote share from 2012 to 2016 . Just as rising integration of Blacks and Latinos made them vulnerable to risky lending (e.g. Fischer and Tienda 2006; Hwang, Hankinson, and Brown 2015), ensuing foreclosures among Blacks could plausibly affect voting activity and turnout among Latino neighbours, a possibility that merits further study.

Third, I find corroborating evidence for individual- and precinct-level links between the housing crisis and swings in the 2016 election. Lagging home values and Latino foreclosures predict significantly lower Democratic presidential candidate vote shares relative to 2012. The effects are not trivial. A one-standard deviation change in each would together reduce the magnitude of the vote swing by almost half. Notably, adding established rival explanations to the model reduce, but fail to erase, the substantial effects of house price changes and Latino foreclosures on the Democratic vote shift in Florida, whether class (percent White college educated), religious (percent LDS), racial (percent White), or ethnic origin (percent Cuban origin Hispanic) variables. The persistence of the significant effect of Latino foreclosure rates after controlling for percent Cuban origin strengthens my argument for two additional reasons. First, Cuban areas experienced fewer foreclosures (Cahill and Franklin 2013); second, Cuban American voters were more likely to vote for the Republican candidate than in 2012 (Valdes 2016). While I have not yet collected the statewide data necessary to directly test the mediating effect of non-Republican Latino voter inactivity, the findings on Latino foreclosures are consistent with that hypothesis. ${ }^{8}$

Taken together, the findings here suggest that vanishing wealth in the housing crisis led to vanishing Democratic votes by (1) deactivating Latino Democrats and Latino Independents, but not Latino Republicans; (2) depressing turnout in minority areas with more Black foreclosures; and (3) potentially activating voters, mainly Whites, in areas that lagged in the housing recovery where more White homeowners were underwater. ${ }^{9}$ The evidence is consistent with other research that finds White voters who perceived themselves to be left behind in the economic recovery were more likely to vote for the Republican candidate, including White Democrats who switched votes from 2012 to 2016 (Rothwell and Diego-Rosell 2016; Zonta and Edelman 2016). ${ }^{10}$

This article makes several contributions to the literature on residential racial stratification and the housing crisis. It advances beyond the beyond Black/White binary in examining the determinants of housing wealth among an unusually diverse Latino population in an emerging immigrant gateway with a significant Puerto Rican diaspora. It is also the first study that establishes specific connections between the racially and geographically uneven housing recovery and the 2016 election. Notwithstanding these contributions, 
the analysis has potential shortcomings. The borrower identification proxy for immigrant status is directly observed, but obscures overlapping categories such as borrowers who refuse to disclose their identification and undocumented immigrants. The panel data do not record vote choice at individual level, only the ecological level. Future research should focus on the potentially pivotal role of mixed status households and the influence of wealth holdings in countries of origin (Flippen 2019; Keister, Vallejo, and Smith 2019). The data here only recorded a handful of such couples based on identification type, surely an understatement. Moreover, voter inactivity, while recorded in proper post-crisis time order, should be adjusted for past inactivity, and should be examined for all precincts in Florida, not just in the Orlando area, in order to uncover potentially important cleavages among Cuban American and other voters.

\section{Conclusion}

The racial position of Latinos in the uneven housing crisis recovery illustrates how the colour line continues to evolve and stratify society on the basis of race. The stunning evaporation of wealth harmed not only harmed vulnerable Latino immigrants; it also structured the exclusion of Latino voters and helped shift Florida from a blue state in 2012 to a red state in 2016. In majority-minority Orlando, and rapidly diversifying Florida, these findings are a reminder that Latinos' impending 'numerical majority does not translate to equality' (Flores-González 2017, 4).

My analysis also has implications for Latino political engagement. I find that Latino Republican voters appear to respond more like other (White) Republicans than other Latinos, which holds important racial and electoral implications as the Latino share of the population continues to rise. The results of the recent 2018 general election in Florida bolster my findings. First, there is a near perfect correlation $(r=0.99)$ between the county-level Democratic vote share in the 2016 presidential election and the 2018 US Senate election (Author's calculations; see also Isbell 2018). Second, the swing towards Democratic statewide candidates in Florida was less than one point compared to the statewide presidential election, far less than the national swing in federal election contests (e.g. +9 points towards Democrats in US House races). Third, the persistence of Republican voting among Florida Latino voters differed from Texas, where there are also a substantial number of (mainly Mexican American) Latino Republicans, but a historic swing towards Democratic candidates (Krogstad, Flores, and Lopez 2018). Recent scholarship has argued that long-awaited increases in Latino voter turnout in 2016 (and 2018) may be the harvest of seeds planted by the largest immigrant rights demonstrations in US history in 2006 (Zepeda-Millán 2017). However, results from 2016 and 2018 strongly suggest that a more entrenched pattern of partisanship has taken hold among Florida voters, including Latinos. In Florida, there are relatively few Mexican origin Latinos, yet a disproportionately higher share of Puerto Ricans (more Democratic yet less active), and Cubans and South Americans (more Republican and more active). This mix of Latino nationalities, partisanship, and voter activity stands out yet informs the future of elections elsewhere because the century-long wave of Mexican immigration is over and the US Latino population is becoming more native born and less Mexican and with each passing year. To be sure, in the present political climate of anti-immigrant sentiment expressed by Republican elected officials, Latinos (and Asians, women, and college- 
educated Whites) have swung towards Democratic candidates, but the 2018 results in Florida warn against extrapolating that trend forever into the future, when the Latino population may look very different.

Latino racial incorporation in the wake of the housing crisis and recent elections may further solidify a tri-racial divide (Bonilla-Silva 2017; Vargas 2015). In Florida, a Latino racial upper tier remains a relative smaller segment oriented around conservative white racial ideology (e.g. older Cuban voters and leaders like Marco Rubio). Meanwhile, a rapidly growing racial middle increases its power to swing future elections (e.g. newly arrived, self-identified White Puerto Rican and South American suburbanites). A final tier of Latinos remain politically and economically excluded. The exclusion may take the form of de jure disenfranchisement via immigration policy or de facto marginalisation as the crisis reproduces racial gaps in wealth and social mobility. Understanding Latino wealth accumulation and tracing its impact on Latino racial incorporation remains an important task for future research and a pressing concern for US politics and society.

\section{Notes}

1. By comparison, only about $10 \%$ of all Latinos in the US are Puerto Rican (US Census Bureau 2017).

2. Pfeiffer and Morris (2017) do not uncover any significant effects of homeownership at differing stages of the housing boom, bust, and recovery on civic neighbourhood activities; however, their data do not allow them to examine voting participation or differences by race.

3. In Florida and 22 other states foreclosure is a judicial procedure (Lis Pendens filing). Among the matched dataset, the average time from an initial Lis Pendens filing to completed foreclosure and home repossession was 890 days, an important detail I return to in my discussion of Florida versus non-judicial foreclosure states, such as Arizona.

4. Further details about the match criteria for each of these data set merges may be found in the online supplement.

5. The pattern of results that I uncover is broadly consistent using logistic, probit, multinomial, and hazard modelling approaches (available upon request).

6. I estimate OCLTV for purchase loans using merged property sales records at the parcel level from the Orange County Property Appraiser. For securitised loans, I use merged loan-level OCLTV from Private Label and Government Sponsored Enterprise mortgage backed securities records $(N=4,288$; see Rugh and Allen 2015). Original home equity is the difference between the value of the property value minus the combined first and second loan balance. Upon prepayment, foreclosure, or December 2016, end CLTV is available from securities data or imputed based on zip code home price changes, ARM terms and rates, amortisation, and length of delinquency (see online appendix for more details).

7. Due to multi-collinearity, I am unable to include the (insignificant) percent White voter inactive variable.

8. Other heavily Latino Sunbelt states present an instructive counterfactual scenario for what may have transpired if there were a stronger (or weaker) recovery in home values in Florida. Latinos make up 25\% of the population in Florida, $29 \%$ in Nevada, $31 \%$ in Arizona, and 39\% in California and Texas. Based on my findings, a stronger housing recovery, more in line with most of these peer states, would imply fewer Latino foreclosures, smaller reductions in wealth, fewer inactive non-Republican Latino voters, and an increased Democratic vote share in 2016. In Florida, the weighted average of county home prices increased by $14 \%$ from 2004 to 2016 and the Democratic vote share decreased by 2 points from 2012 to 2016. In Arizona, California, and Texas, weighted home prices increased by 21, 24, and 46\%, respectively, in the counties with available data (14 of 15 in Arizona, 55 of 58 in California, 144 of 254 in Texas). As the recovery figures suggest, among these 
three states, the weighted Democratic vote share increased by 5 points, 6 points, and 6 points, respectively, in counties with available home price data. Thus, unlike Florida, the Democratic vote share did not decrease in Arizona, California, or Texas, where exit polls reported a similar share of Latinos voting for the Republican candidate as in Florida (CNN 2016). Unlike these states, the housing market in Nevada has been weaker than in Florida and has not recovered; home prices have decreased by $3 \%$. As expected, the Democratic vote share also declined more than in Florida, by 4 points. This counterfactual comparison, partly explains why, all else equal, Arizona, California, and Texas trended more Democratic, but Florida and Nevada did not. To be sure, shifts in the 2016 election outcome have multiple causes, including the class, religious, and racial profile of the population. However, this comparison strongly suggests the housing market recovery helped played a role and warrants further investigation.

9. Other evidence supports the notion that foreclosures and vanishing home equity influenced the election outcome mainly by tilting the composition of Florida voters in 2016 towards White and Latino Republican voters. First, it is highly unlikely that the housing fallout systematically affected the widespread, uniform, and steep drop-off in Black voter turnout nationwide and across Florida precincts and counties (File 2017; Florida Division of Elections 2017). Second, in my matched homeowner-voter dataset, partisanship varies by Hispanic surname status. Specifically, $18 \%$ of Latinos with a Hispanic surname are registered as a Republican, versus $27 \%$ among those without a Hispanic surname. Hispanic surname status is simultaneously a marker of immigrant integration, intermarriage, and racial integration into the non-Hispanic white mainstream as well as risk factor for foreclosure (net of controls). These cleavages by party and ethnicity underscore how the diversity of the Latino population in Florida contributes to the disappearance of Democratic votes in 2016. Consequently, I conclude that any effect of the housing crisis indeed likely hinges on the mediating influence of non-Republican Latino voter inactivity in response to Latino foreclosures and lost wealth and differential White voter response to the lagging recovery.

10. In economic, psychological, political, and sociological perspective, the residual effects of the housing crisis may help explain the elevated support for the Republican candidate among White homeowners with higher incomes and apparently more stable economic prospects relative to the white working class. While rising household wealth confers an endowment effect that boosts consumption (Case, Quigley, and Shiller 2011), evidence from prospect theory shows that losses are valued more than equivalent gains (Tversky and Kahneman 1991). To understand why the endowment effect appears more pronounced for Whites than non-Whites (see Table 5, Figures 3 and 4), we must assess the structural importance of race in social and political context. As other areas and owners recover, the persistence of time and social distance may magnify the perceived sense of loss and even spur White resentment. In the pair of maps in Figure 1, most of the counties in Florida that have not recovered from the housing crisis are exurban areas populated heavily by Whites but which surround urban areas that have recovered, and are far more racially diverse. In 2012, most Florida counties had not recovered, regardless of location; by 2016, the urbanexurban/rural divide in Figure 1 had emerged. Thus, in 2016 especially, White homeowners in areas where the housing crisis lingered, however mildly, might perceive that non-Whites were faring better economically, even if the balance of evidence suggests otherwise. Furthermore, if Whites perceive that non-White economic success comes at the expense of Whites, then White reaction to the housing crisis could readily be racialized, an outcome supported by recent cutting-edge research in political science (Luttig, Federico, and Lavine Forthcoming). The racial effects of time and social distance were indeed apparently amplified by a Republican candidate campaign that deployed the Latino immigrant threat narrative at its inception (Abrajano and Hajnal 2015; Enos 2017). Support would accumulate among White voters, including affluent homeowners, if offered a zero sum bargain between improving their (relatively) dwindled economic prospects and the inexorable demographic increase in the non-White population (Haney-López 2015; Major, Blodorn, and Blascovich 2016). 
Under these conditions, the only surprise would be if the response of White voters to the crisis were not racialized by the racial appeals of the 2016 Republican campaign (Tesler 2016).

\section{Acknowledgements}

I thank the editors, reviewers, and colleagues in the BYU Department of Political Science for their helpful comments and Conrad Ashby, Alejandra Aducin Bradford, Sage Clark, Alyssa Clark, Daehyeon Kim, and Sarah Pace for their research assistance.

\section{Disclosure statement}

No potential conflict of interest was reported by the author.

\section{References}

Abrajano, Marisa, and Zoltan L. Hajnal. 2015. White Backlash: Immigration, Race, and American Politics. Princeton, NJ: Princeton University Press.

Alba, Richard. 2009. Blurring the Color Line: The New Chance for a More Integrated America. Cambridge, MA: Harvard University Press.

Allen, Ryan. 2011. "The Relationship between Residential Foreclosures, Race, Ethnicity, and Nativity Status." Journal of Planning Education and Research 31 (2): 125-142.

Bean, Frank D., Susan K. Brown, and James D. Bachmeier. 2015. Parents without Papers. New York: Russell Sage Foundation.

Bonilla-Silva, Eduardo. 2017. Racism Without Racists: Color-Blind Racism and the Persistence of Racial Inequality in America. 5th ed. New York: Rowman \& Littlefield.

Brown, Susan K. 2007. "Delayed Spatial Assimilation: Multigenerational Incorporation of the Mexican-origin Population in Los Angeles." City \& Community 6 (3): 193-209.

Cahill, Meagan E., and Rachel S. Franklin. 2013. "The Minority Homeownership Gap, Foreclosure, and Nativity: Evidence from Miami-Dade County." Journal of Regional Science 53 (1): 91-117.

Case, Karl E., John M. Quigley, and Robert J. Shiller. 2011. Wealth Effects Revisited 1978-2009 (Working Paper No. 16848). Cambridge, MA: National Bureau of Economic Research.

Chavez, Leo. 2013. The Latino Threat. Stanford, CA: Stanford University Press.

CNN. 2016. "Election 2016 Exit Polls." https://www.cnn.com/election/2016/results/exit-polls.

Conley, Dalton. 2010. Being Black, Living in the Red. Berkeley: University of California Press.

Dowling, Julie. 2014. Mexican Americans and the Question of Race. Austin, TX: University of Texas Press.

Dreby, Joanna. 2015. Everyday Illegal. Berkeley, CA: University of California Press.

Duany, Jorge. 2010. "The Orlando Ricans: Overlapping Identity Discourses among Middle-Class Puerto Rican Immigrants." Centro Journal 22 (1): 85-115.

Duany, Jorge, and Félix V. Matos Rodríguez. 2006. Puerto Ricans in Orlando and Central Florida. Vol. 1. No. 1. New York: Centro de Estudios Puertorriqueños, Hunter College (CUNY).

Emeka, Amon. 2019. "Free and Clear: National Origins and Progress Toward Unencumbered Homeownership among Post-Civil Rights Era Immigrants in the US.” Journal of Ethnic and Migration Studies. doi:10.1080/1369183X.2019.1592876.

Enos, Ryan D. 2017. The Space Between Us: Social Geography and Politics. Cambridge, UK: Cambridge University Press.

Estrada-Correa, Vanesa, and Martin Johnson. 2012. "Foreclosure Depresses Voter Turnout: Neighborhood Disruption and the 2008 Presidential Election in California." Social Science Quarterly 93 (3): 559-576. 
Federal Financial Institutions Examination Council (FFIEC). 2006. Home Mortgage Disclosure Act (HMDA): Loan Application Register (LAR) Raw Data, 2004-2005. 2006 (September 2006). Accessed February 2, 2008. http://www.ffiec.gov/hmda/hmdaflat.htm.

Federal Financial Institutions Examination Council (FFIEC). 2011. Home Mortgage Disclosure Act (HMDA): Loan Application Register (LAR) Raw Data, 2006-2007. 2011. ICPSR24611-v1ICPSR24612-v1. Ann Arbor, MI: Inter-university Consortium for Political and Social Research [distributor], 2010-06-03. http://doi.org/10.3886/ICPSR24611.v1.

File, Thom. 2017. "Voting in America: A Look at the 2016 Presidential Election." Social, Economic and Housing Statistics Division, US Census Bureau. https://www.census.gov/newsroom/blogs/ random-samplings/2017/05/voting_in_america.html.

Fischel, William. 2001. The Homevoter Hypothesis. Cambridge, MA: Harvard University Press.

Fischer, Mary J., and Marta Tienda. 2006. "Redrawing Spatial Color Lines: Latino Metropolitan Dispersal, Segregation, and Economic Opportunity." In Latinos and the Future of America, edited by Marta Tienda and Faith Mitchell, 100-137. Washington, DC: National Academies Press.

Flippen, Chenoa A. 2010. “The Spatial Dynamics of Stratification: Metropolitan Context, Population Redistribution, and Black and Hispanic Homeownership.” Demography 47 (4): 845-868.

Flippen, Chenoa A. 2019. "The Uphill Climb: A Transnational Perspective on Wealth Accumulation among Latino Immigrants in Durham, NC.” Journal of Ethnic and Migration Studies. doi:10.1080/1369183X.2019.1592873.

Flores-González, Nilda. 2017. Citizens but Not Americans: Race and Belonging among Latino Millennials. New York: New York University Press.

Florida Division of Elections. 2017. "Elections Data." http://dos.myflorida.com/elections/datastatistics/elections-data/.

Frey, William H. 2018. Diversity Explosion: How New Racial Demographics Are Remaking America. Washington, DC: Brookings Institution Press.

Glaeser, Edward L., Joseph Gyourko, and Albert Saiz. 2008. "Housing Supply and Housing Bubbles." Journal of Urban Economics 64 (2): 198-217.

Golash-Boza, Tanya. 2006. "Dropping the Hyphen? Becoming Latino(a)-American Through Racialized Assimilation." Social Forces 85 (1): 27-55.

Golash-Boza, Tanya. 2015. Deported: Immigrant Policing, Disposable Labor and Global Capitalism. New York: New York University Press.

Goldsmith, Arthur H., Darrick Hamilton, and William Darity. 2007. "From Dark to Light: Skin Color and Wages among African-Americans." Journal of Human Resources 42 (4): 701-738.

Hall, Matthew, Kyle Crowder, and Amy Spring. 2015a. "Neighborhood Foreclosures, Racial/Ethnic Transitions, and Residential Segregation." American Sociological Review 80 (3): 526-549.

Hall, Matthew, Kyle Crowder, and Amy Spring. 2015b. "Variations in Housing Foreclosures by Race and Place, 2005-2012." The ANNALS of the American Academy of Political and Social Science 660 (1): 217-237.

Hall, Andrew B., Jesse Yoder, and Nishant Karandikar. 2017. "Economic Distress and Voting: Evidence from The Subprime Mortgage Crisis.” SocArXiv. https:/osf.io/preprints/socarxiv/ 9 ptqc/.

Haney-López, Ian. 2015. Dog Whistle Politics. New York: Oxford University Press.

Healy, Andrew, and Lenz Gabriel S. 2017. "Presidential Voting and the Local Economy: Evidence from Two Population-based Data Sets." The Journal of Politics 79 (4): 1419-1432.

Healy, Andrew, and Neil Malhotra. 2013. "Retrospective Voting Reconsidered." Annual Review of Political Science 16: 285-306.

Holian, Matthew J. 2011. "Homeownership, Dissatisfaction and Voting." Journal of Housing Economics 20 (4): 267-275.

Hwang, Jackelyn, Michael Hankinson, and Kreg Steven Brown. 2015. "Racial and Spatial Targeting: Segregation and Subprime Lending Within and Across Metropolitan Areas." Social Forces 93 (3): 1081-1108.

Isbell, Matthew C. 2018. "How Florida's Congressional Districts Voted in 2018." http://mcimaps. com/2018-congress/. 
Keister, Lisa A., and Stephanie Moller. 2000. "Wealth Inequality in the United States." Annual Review of Sociology 26: 63-81.

Keister, Lisa A., Jody Agius Vallejo, and E. Paige Borelli. 2015. "Mexican American Mobility: Early Life Processes and Adult Wealth Ownership." Social Forces 93 (3): 1015-1046.

Keister, Lisa A., Jody Agius Vallejo, and Paige Borelli Smith. 2019. "Investing in the Homeland: Cross-Border Investments and Immigrant Wealth in the U.S." Journal of Ethnic and Migration Studies. doi:10.1080/1369183X.2019.1592875.

Killewald, Alexandra. 2013. "Return to Being Black, Living in the Red: A Race Gap in Wealth That Goes Beyond Social Origins.” Demography 50 (4): 1177-1195.

Kim, Jeongseob, and Gi-Hyoug Cho. 2016. "Unending Foreclosure Crisis: Uneven Housing Tenure Trajectories of Post-REO Properties.” Applied Geography 70: 49-58.

Krogstad, Jens Manuel, Antonio Flores, and Mark Hugo Lopez. 2018. "Key Takeaways about Latino Voters in the 2018 Midterm Elections.” Pew Research Center. http://www.pewresearch.org/facttank/2018/11/09/how-latinos-voted-in-2018-midterms/.

Kuebler, Meghan, and Jacob S. Rugh. 2013. "New Evidence on Racial and Ethnic Disparities in Homeownership in the United States From 2001 to 2010.” Social Science Research 42 (5): 1357-1374.

Lauren J., Krivo, and Robert L. Kaufman. 2004. "Housing and Wealth Inequality: Racial-ethnic Differences in Home Equity in the United States.” Demography 41 (3): 585-605.

Lei, Serena, Signe-Mary McKernan, Caroline Ratcliffe, C. Eugene Steuerle, Caleb Quakenbush, and Emma Kalish. 2017. "Nine Charts about Wealth Inequality in America." Urban Institute. http:// apps.urban.org/features/wealth-inequality-charts/.

López, Jane Lilly. 2015. "Impossible Families': Mixed-Citizenship Status Couples and the Law." Law \& Policy 37 (1-2): 93-118.

Luttig, Matthew, Christopher Federico, and Howard Lavine. Forthcoming. "Supporters and Opponents of Donald Trump Respond Differently to Racial Cues: An Experimental Analysis." Research \& Politics.

Major, Brenda, Alison Blodorn, and Gregory Major Blascovich. 2016. "The Threat of Increasing Diversity: Why Many White Americans Support Trump in the 2016 Presidential Election.” Group Processes \& Intergroup Relations 21: 931-940. doi:1368430216677304.

Maroto, Michelle. 2016. "Growing Farther Apart: Racial and Ethnic Inequality in Household Wealth Across the Distribution." Sociological Science 3: 801-824.

Massey, Douglas S. 2007. Categorically Unequal: The American Stratification System. New York: Russell Sage Foundation.

Massey, Douglas S., and Amelie Constant. 2017. "Latinos in the Northeastern United States: Trends and Patterns." No. 60. GLO Discussion Paper.

Massey, Douglas S., and Nancy A. Denton. 1993. American Apartheid: Segregation and the Making of the Underclass. Cambridge, MA: Harvard University Press.

Massey, Douglas S., Jorge Durand, and Karen A. Pren. 2016. "Why Border Enforcement Backfired." American Journal of Sociology 121 (5): 1557-1600.

McCartney, William. 2017. "Household Financial Distress and Voter Participation." November 11, 2017. https://ssrn.com/abstract=3068596.

McConnell, Eileen Díaz. 2008. “U.S. Latinos/as and the 'American Dream': Diverse Populations and Unique Challenges in Housing." In Latinas/os in the United States: Changing the Face of America, edited by Havidan Rodríguez, Rogelio Saenz, and Cecilia Menjívar, 87-100. Boston, MA: Springer US.

McConnell, Eileen Díaz. 2015. "Hurdles or Walls? Nativity, Citizenship, Legal Status and Latino Homeownership in Los Angeles.” Social Science Research 53: 19-33.

McConnell, Eileen Díaz, and Ilana Redstone Akresh. 2013. "Home Equity of New Legal Immigrants in the United States: An Evaluation of Three Key Theoretical Perspectives." International Migration Review 47 (3): 686-729.

Mood, Carina. 2010. "Logistic Regression: Why We Cannot Do What We Think We Can Do, and What We Can Do About It.” European Sociological Review 26 (1): 67-82. 
Myers, Dowell. 2007. Immigrants and Boomers: Forging a New Social Contract for the Future of America. New York, NY: Russell Sage Foundation.

Oliver, Melvin L., and Thomas M. Shapiro. 2006. Black Wealth, White Wealth. New York: Taylor \& Francis.

Owens, Lindsay A., and Karen S. Cook. 2013. "The Effects of Local Economic Conditions on Confidence in Key Institutions and Interpersonal Trust After the Great Recession." The ANNALS of the American Academy of Political and Social Science 650 (1): 274-298.

Painter, Matthew A., and Zhenchao Qian. 2016. "Wealth Inequality among Immigrants: Consistent Racial/Ethnic Inequality in the United States." Population Research and Policy Review 35 (2): $147-175$.

Painter, Matthew A., and Zhenchao Qian. 2015. "Wealth Inequality among New Immigrants." Sociological Perspectives 59 (2): 368-394.

Park, Julie, and Dowell Myers. 2010. "Intergenerational Mobility in the Post-1965 Immigration Era: Estimates by an Immigrant Generation Cohort Method.” Demography 47 (2): 369-392.

Pfeiffer, Deirdre, and Eric A. Morris. 2017. "Are Homeowners Better Neighbors During Housing Booms? Understanding Civic and Social Engagement by Tenure During the Housing Market Cycle." Cityscape (Washington, D C) 19 (2): 215-238.

Portes, Alejandro, and Min Zhou. 1993. "The New Second Generation: Segmented Assimilation and Its Variants." The Annals of the American Academy of Political and Social Science 530 (1): 74-96.

Raymond, Elora, Kyungsoon Wang, and Dan Immergluck. 2016. "Race and Uneven Recovery: Neighborhood Home Value Trajectories in Atlanta Before and After the Housing Crisis." Housing Studies 31 (3): 324-339.

Reeves, Andrew, and James G. Gimpel. 2012. "Ecologies of Unease: Geographic Context and National Economic Evaluations." Political Behavior 34 (3): 507-534.

Reid, Carolina K., Debbie Bocian, Wei Li, and Roberto G. Quercia. 2017. "Revisiting the Subprime Crisis: The Dual Mortgage Market and Mortgage Defaults by Race and Ethnicity." Journal of Urban Affairs 39 (4): 469-487.

Rogers, Jonathan. 2016. "Tea Party Support and Perceptions of Local Economic Conditions." Electoral Studies 42: 91-98.

Ross, Lauren M., and Gregory D. Squires. 2011. “The Personal Costs of Subprime Lending and the Foreclosure Crisis: A Matter of Trust, Insecurity, and Institutional Deception.” Social Science Quarterly 92 (1): 140-163.

Rothwell, Jonathan T. and Diego-Rosell, Pablo. 2016. "Explaining Nationalist Political Views: The Case of Donald Trump.” http://doi.org/10.2139/ssrn.2822059.

Rugh, Jacob S. 2015a. "Double Jeopardy: Why Latinos Were Hit Hardest by the US Foreclosure Crisis." Social Forces 93 (3): 1139-1184.

Rugh, Jacob S. 2015b. "Painting the Whole Picture: Foreclosure Rates among Asian American Ethnic Groups in Orlando, Florida, and Phoenix, Arizona." AAPI Nexus: Asian Americans and Pacific Islanders Policy, Practice \& Community 13 (1-2): 149-177. http://doi.org/10. 17953/1545-0317.13.1.149.

Rugh, Jacob S., and Ryan Allen. 2015. "Using Original Data to Uncover Pathways to Latino Disparities in Foreclosure." Paper presented at the Meeting of urban Affairs association, Miami, FL.

Rugh, Jacob S., and Matthew Hall. 2016. "Deporting the American Dream: Immigration Enforcement and Latino Foreclosures.” Sociological Science 3: 1053-1076. doi:10.15195/v3.a46.

Rugh, Jacob S., and Douglas S. Massey. 2010. "Racial Segregation and the American Foreclosure Crisis." American Sociological Review 75 (5): 629-651.

Salgado, Casandra D., and Vilma Ortiz. 2019. "Mexican Americans and Wealth: Economic Status, Family and Place." Journal of Ethnic and Migration Studies. doi:10.1080/1369183X.2019. 1592878.

Sharkey, Patrick. 2013. Stuck in Place: Urban Neighborhoods and the End of Progress Toward Racial Equality. Chicago: University of Chicago Press. 
Silver, Nate. 2016. "Education, Not Income, Predicted Who Would Vote For Trump." FiveThirtyEight. November 22, 2016. http://fivethirtyeight.com/features/education-notincome-predicted-who-would-vote-for-trump/.

Silver, Nate. 2017. “Clinton's Ground Game Didn't Cost Her The Election.” FiveThirtyEight. February 13, 2017. https://fivethirtyeight.com/features/clintons-ground-game-didnt-cost-herthe-election/.

Singer, Audrey. 2004. The Rise of New Immigrant Gateways. Washington, DC: Center on Urban and Metropolitan Policy, the Brookings Institution. https://www.brookings.edu/wp-content/ uploads/2016/06/20040301_gateways.pdf.

Singer, Audrey. 2015. A Typology of Immigrant Gateways, 2014. Washington, DC: Metropolitan Policy Program, the Brookings Institution. https://www.brookings.edu/wp-content/uploads/ 2016/07/Gateways-2014-update-1.pdf.

Strom, Elizabeth, and Steven Reader. 2013. "Rethinking Foreclosure Dynamics in a Sunbelt City: What Parcel-Level Mortgage Data Can Teach Us About Subprime Lending and Foreclosures." Housing Policy Debate 23 (1): 59-79.

Taylor, Paul, Rakesh Kochhar, Richard Fry, Gabriel Velasco, and Seth Motel. 2011. Wealth Gaps Rise to Record Highs between Whites, Blacks and Hispanics. Washington, DC: Pew Research Center. (2011): 37.

Telles, Edward E., and Vilma Ortiz. 2008. Generations of Exclusion. New York: Russell Sage Foundation.

Tesfai, Rebbeca. 2017. "Continued Success or Caught in the Housing Bubble? Black Immigrants and the Housing Market Crash.” Population Research and Policy Review 36 (4): 531-560.

Tesler, Michael. 2016. Post-Racial or Most-Racial? Chicago: University of Chicago Press.

Tienda, Marta, and Norma Fuentes. 2014. "Hispanics in Metropolitan America: New Realities and Old Debates." Annual Review of Sociology 40: 499-520.

Tversky, Amos, and Daniel Kahneman. 1991. "Loss Aversion in Riskless Choice: A ReferenceDependent Model." The Quarterly Journal of Economics 106 (4): 1039-1061.

U.S. Census Bureau. 2017. "2016 American Community Survey 1-Year Estimates." Accessed September 24, 2017. https://www.census.gov/acs/www/data/data-tables-and-tools/americanfactfinder/.

Valdes, Marcela. 2016. "We're Looking at a New Divide within the Hispanic Community." New York Times Magazine. https://www.nytimes.com/interactive/2016/11/20/magazine/ donald-trumps-america-florida-latino-vote.html?_r=0.

Vallejo, Jody Agius. 2012. Barrios to Burbs. Stanford, CA: Stanford University Press.

Vallejo, Jody Agius, and Lisa A. Keister. 2019. "Immigrants and Wealth Attainment: Migration, Inequality, and Integration.” Journal of Ethnic and Migration Studies. doi:10.1080/1369183X. 2019.1592872.

Vargas, Nicholas. 2015. "Latina/o Whitening? Which Latina/os Self-Classify as White and Report Being Perceived as White by Other Americans?” Du Bois Review: Social Science Research on Race 12 (1): 119-136.

Zayas, Luis H. 2015. Forgotten Citizens. New York: Oxford University Press.

Zepeda-Millán, Chris. 2017. Latino Mass Mobilization: Immigration, Racialization, and Activism. Cambridge: Cambridge University Press.

Zonta, Michela, and Sarah Edelman. 2016. The Role of Midwestern Housing Instability in the 2016 Election. Economy Issues. Washington, DC: Center for American Progress. https://www. americanprogress.org/issues/economy/news/2016/11/29/293816/the-role-of-midwesternhousing-instability-in-the-2016-election/. 